\title{
Review \\ Opportunities and Barriers for Valorizing Waste Incineration Bottom Ash: Iberian Countries as a Case Study
}

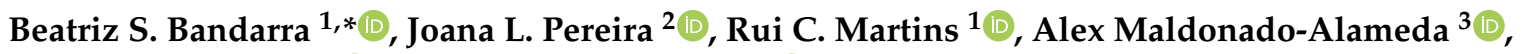 \\ Josep M. Chimenos ${ }^{3}$ (i) and Margarida J. Quina ${ }^{1}$ (D) \\ 1 University of Coimbra, CIEPQPF, Department of Chemical Engineering, Rua Sílvio Lima, \\ Pólo II—Pinhal de Marrocos, 3030-790 Coimbra, Portugal; martins@eq.uc.pt (R.C.M.); guida@eq.uc.pt (M.J.Q.) \\ 2 CESAM-Centre for Environmental and Marine Studies, Department of Biology, University of Aveiro, \\ 3810-193 Aveiro, Portugal; jpereira@ua.pt \\ 3 Departament de Ciència de Materials i Química Física, Universitat de Barcelona, C/Martí i Franquès 1, \\ 08028 Barcelona, Spain; alex.maldonado@ub.edu (A.M.-A.); chimenos@ub.edu (J.M.C.) \\ * Correspondence: bsbandarra@eq.uc.pt; Tel.: +351-239798700
}

check for updates

Citation: Bandarra, B.S.; Pereira, J.L.; Martins, R.C.; Maldonado-Alameda,

A.; Chimenos, J.M.; Quina, M.J.

Opportunities and Barriers for

Valorizing Waste Incineration Bottom Ash: Iberian Countries as a Case Study. Appl. Sci. 2021, 11, 9690. https://doi.org/10.3390/app11209690

Academic Editors: Graça Martinho and Nuno Lapa

Received: 15 September 2021

Accepted: 11 October 2021

Published: 18 October 2021

Publisher's Note: MDPI stays neutral with regard to jurisdictional claims in published maps and institutional affiliations.

Copyright: (c) 2021 by the authors. Licensee MDPI, Basel, Switzerland. This article is an open access article distributed under the terms and conditions of the Creative Commons Attribution (CC BY) license (https:// creativecommons.org/licenses/by/ $4.0 /)$

\begin{abstract}
Incineration bottom ashes (IBA) are the main waste from municipal solid waste (MSW) incineration. In the Iberian countries (Portugal and Spain), MSW incineration with energy recovery (WtE) plays an important role in MSW management. IBA is highly produced and managed differently both between and within countries. This paper aims to provide a comprehensive overview of the management model of IBA using the Iberian Peninsula as a case study, addressing its properties, current management, incentives and difficulties in valorizing, and prospects. For this purpose, incineration plants of both countries were approached, and a broad literature review was conducted to gather information. About $10 \%$ and $41 \%$ of IBA have been landfilled in Portugal and Spain, respectively. Metals (mostly ferrous) from Portuguese (6\% of IBA) and Spanish (9\% of IBA) WtE plants are recycled. In Portugal, the remaining IBA (84\%) has been temporarily stored (11\%), applied to landfills as a substitute for soil in intermediate and final covers, construction of paths, accesses, and platforms (41\%), or used in civil engineering work and road construction (48\%). In Spain, the remaining IBA $(50 \%)$ has been reused mainly as a secondary raw material in the construction and civil engineering fields (77\%), while the rest has been temporarily stored (11\%), applied in the conditioning of landfills (4\%), alsoa secondary aggregate replacing natural materials. Both countries regulate IBA reuse outside landfills but consider different requirements and criteria. Nevertheless, there are both drivers and barriers to valorization. In the future, different IBA applications will likely continue to be developed, with the concern of protecting the environment. Growing confidence in IBA reuse following the publication of proper studies is expected. Globally, uniform legal frameworks among EU members with the same standards would likely lead to better IBA valorization.
\end{abstract}

Keywords: incineration bottom ashes; IBA; Iberian countries; management; valorization; reuse

\section{Introduction}

Socioeconomic activities inevitably result in the generation of waste. Even the most advanced programs for waste reduction, collection, recycling, and treatment cannot avoid the generation of residual waste streams. In fact, generated wastes are a sink for harmful and unrecoverable substances, and some authors have linked it to the impossibility of the practical accomplishment of the "zero waste" strategy [1,2]. On the other hand, waste must be managed to protect the environment and human health. One of the main goals of waste management policies in the European Union (EU) is to reduce waste production. Nevertheless, the generation of municipal solid waste (MSW) in the EU-27 has been steadily increasing, amounting to near $222 \mathrm{Mt}(496 \mathrm{~kg}$ per capita) in 2018 [3]. The same trend was observed in Iberian countries, i.e., Portugal and Spain. In Portugal, although the National strategic plan for MSW 2014-2020 [4] intended to reduce the amount generated, the MSW 
production has been increasing in the last few years up to about $5.3 \mathrm{Mt}(513 \mathrm{~kg}$ per capita, higher than the EU average) in 2019 [5]. In 2018, Spain generated $22.3 \mathrm{Mt}$ (486 kg per capita), close to the EU average [6], but still well above the targets set in the Spanish National Waste Management Plan 2016-2022 [7].

The heterogeneous and complex composition of wastes, along with their different origins and relationships with consumption patterns, create huge challenges for MSW management [8]. Currently, MSW incineration in waste-to-energy (WtE) plants is one of the main management strategies adopted in most developed countries. Although in Iberian countries this treatment is not as widespread as in Central Europe [9], MSW incineration with energy recovery has a key role in waste management, allowing the diversion of a significant fraction of wastes from landfills. Incineration in WtE plants decreases the volume and the weight of waste by about $90 \%$ and $70 \%$, respectively $[10,11]$, and the energy may be recovered as electricity and/or heat.

Nonetheless, MSW incineration creates new solid wastes, namely incineration bottom ashes (IBA) and air pollution control residues. IBA is the main solid output from the incineration process, accounting for about $80 \mathrm{wt} . \%$ of all incineration residues [12], and corresponds to the incombustible materials that remain in the furnace after combustion. IBA is produced worldwide, particularly, in Europe [13,14], where around $18 \mathrm{Mt}$ /year of IBA is generated [15]. The management methods currently applied to IBA are not uniform among European countries, where the strategies significantly diverge [15].

In this context, this paper aims at presenting the management model of IBA in the Iberian countries, namely Portugal and Spain, giving information on the properties of IBA, current management systems, motivations, and challenges for its valorization, and finally the expectations for the future in this regard. To the best of our knowledge, this is the first paper providing such a broad overview of the management of IBA using the Iberian Peninsula as a case study. Most data presented in this work was provided or confirmed by the Portuguese and Spanish WtE plants and the Spanish Association of Energy Recovery from MSW (AEVERSU).

\section{Incineration in the Iberian Countries}

In Portugal, although the management system heavily relies on landfills, important progress has been observed towards more sustainable technologies. Indeed, landfilled waste decreased from $72 \%$ to $50 \%$, and the waste recycled (including composting) increased from $8 \%$ to 31\%, between 2002 and 2018 (Figure 1a). On the other hand, although an increase (from $18 \%$ to $26 \%$ ) has been observed at the EU level for incinerated waste, in Portugal almost a consistent $20 \%$ (nearly $1 \mathrm{Mt}$-about $100 \mathrm{~kg}$ per capita) of waste is incinerated $[9,16]$. In Spain, despite the measures promoted by public administrations, landfill is also still the main option for the final management of MSW (Figure 1b). In the past 15 years, the contribution of landfills as a fate for wastes decreased by only $10 \%$ (from $61 \%$ to $51 \%$ ). Consequently, all other treatment options increased slightly but much less than expected, with 18\% of materials recycled from MSW in 2018, 13\% incinerated with energy recovery, and only $17 \%$ of the organic fraction of MSW composted or digested in anaerobic bioreactors [9]. Despite the guidelines and hierarchy established by the European Parliament for the treatment of waste (Directive 2008/98/EC), in which energy recovery from MSW is prioritized over its landfilling, there has generally been a lack of political support and willingness in both countries to increase national incineration capacity. This is probably due to public pressure based on technically and scientifically unfounded fears (e.g., linked to emissions, which are controlled under strict limit values in the EU), misinformation (e.g., the idea that European funds do not support this field), or the hypothesis that incineration will not be necessary if prevention and recycling are implemented instead. Indeed, the Portuguese Association of Entities for Energy Recovery from MSW (AVALER) and the Spanish Association for Energy Recovery from MSW Companies (AEVERSU), along with the general waste management industry, have argued that one of the main challenges for the development of the waste sector is the 
deficient capacity for WtE that could avoid disposal in landfills. As a result of the rising production of waste and the fact that Portugal and Spain continue to landfill about half of their MSW, it is expected that the landfill capacity in most of the national territories will be used up in the near future since new landfills are not planned. WtE creates a final valorizing destination for non-recyclable waste, avoiding waste exportation with the corresponding environmental and financial costs, and may contribute to achieving EU and National landfilling targets. In this context, AVALER made a proposal within the framework of a new Strategic Plan for waste management with an implementation horizon set to 2030 (currently in discussion). This plan intends to create the conditions for valorizing all waste with recovery potential, using a combination of quality recycling and energy recovery of non-recyclable waste [17]. Recycling cannot be $100 \%$ achieved due to the dissipative losses of materials between the life-cycle stages of manufacturing and end-of-life, to the possible loss of the original properties of materials, and to some harmful substances that must be separated to protect human health and the environment. On the other hand, WtE eliminates toxic organic substances and mineralizes the organic components, working as a sink for organic materials (some of them environmental pollutants) [1,2]. Thus, incineration does not substitute recycling but rather supports high-quality recycling [10]. Furthermore, incineration is considered a sanitary method for the treatment of MSW [18] and it works as a buffer for the system in the case of unforeseen events, such as the COVID-19 pandemic, due to its ability to destroy pathogens potentially present in MSW. In fact, recently, the Portuguese Agency for Environment (APA) recommended the preference for incineration as the final destination for the unsorted MSW [19], and WtE plants have been available to operate under full load conditions.

There are 4 MSW incineration plants in Portugal and 12 in Spain, including Andorra (Figure 2). Although it is not located in Spain, it is worth mentioning that the plant located in Andorra (CTRASA) is also a member of the Spanish association of energy recovery plants (AEVERSU).

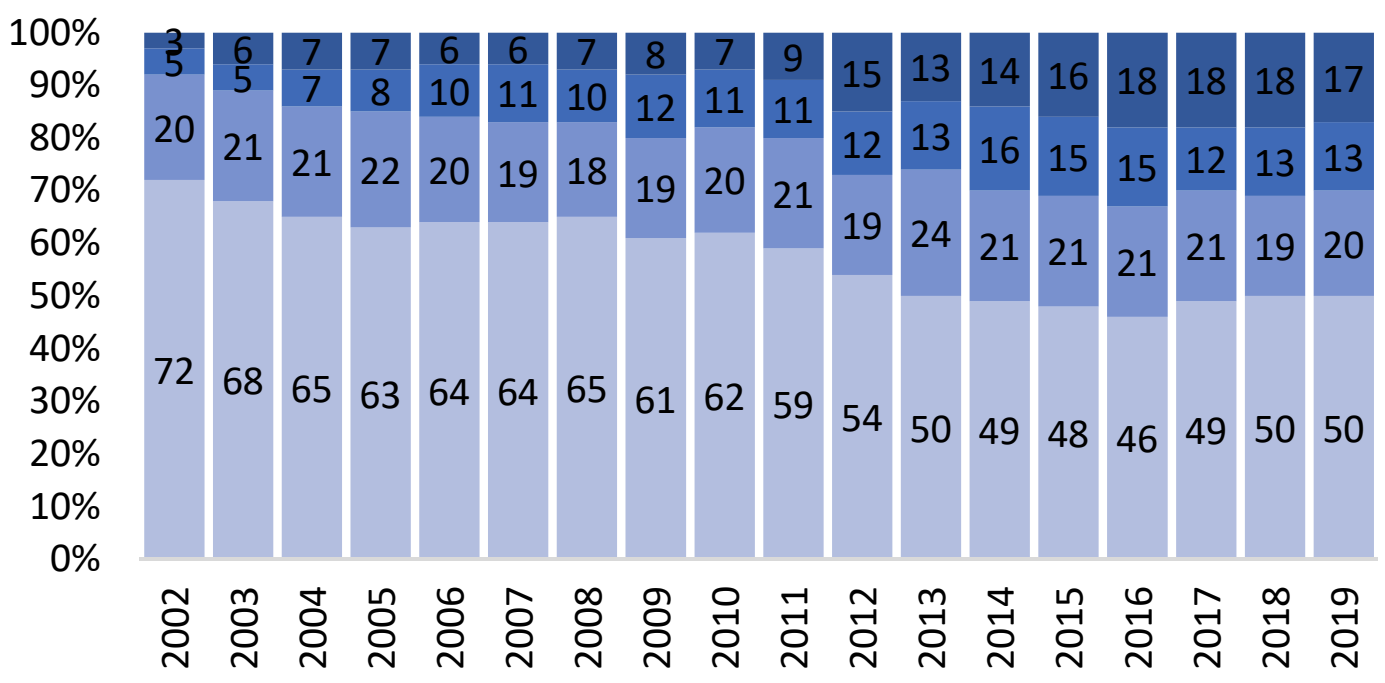

(a)

Landfill Incineration Material Recycling

Figure 1. Cont. 


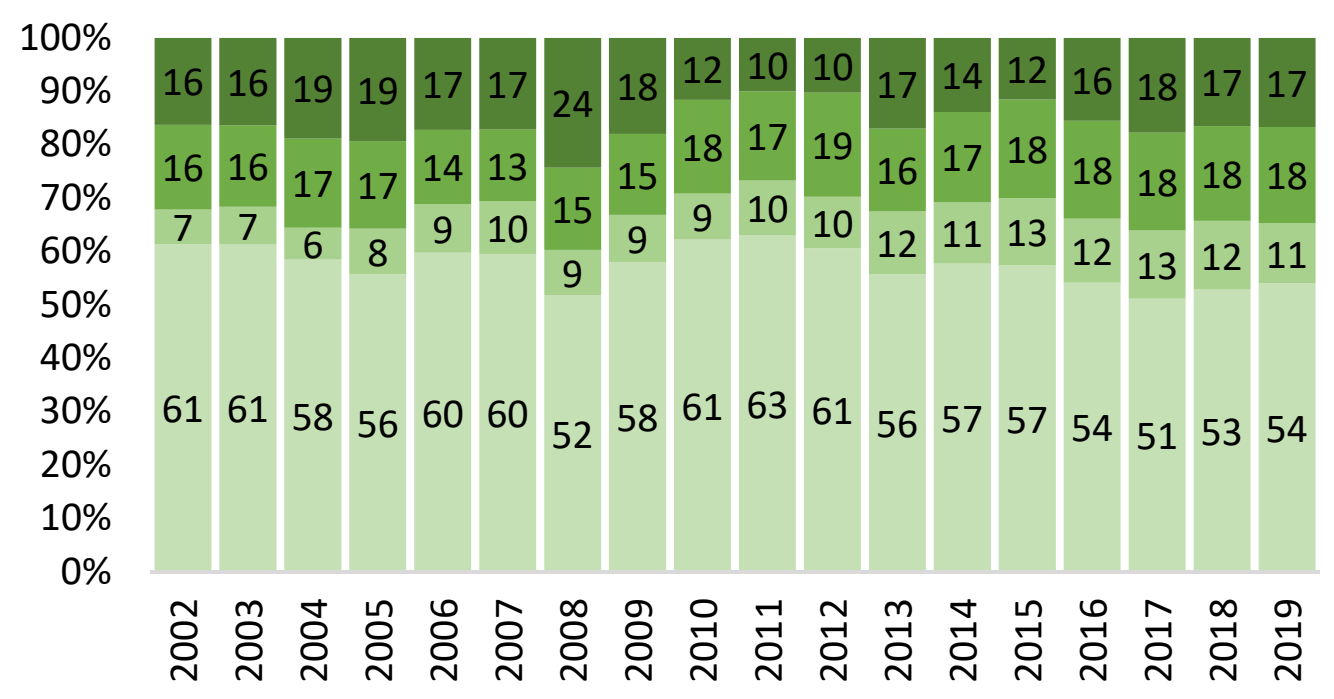

(b)

\section{Landfill Incineration $\square$ Material recycling $\quad$ Composting}

Figure 1. MSW management in (a) Portugal [16]; (b) Spain [9].

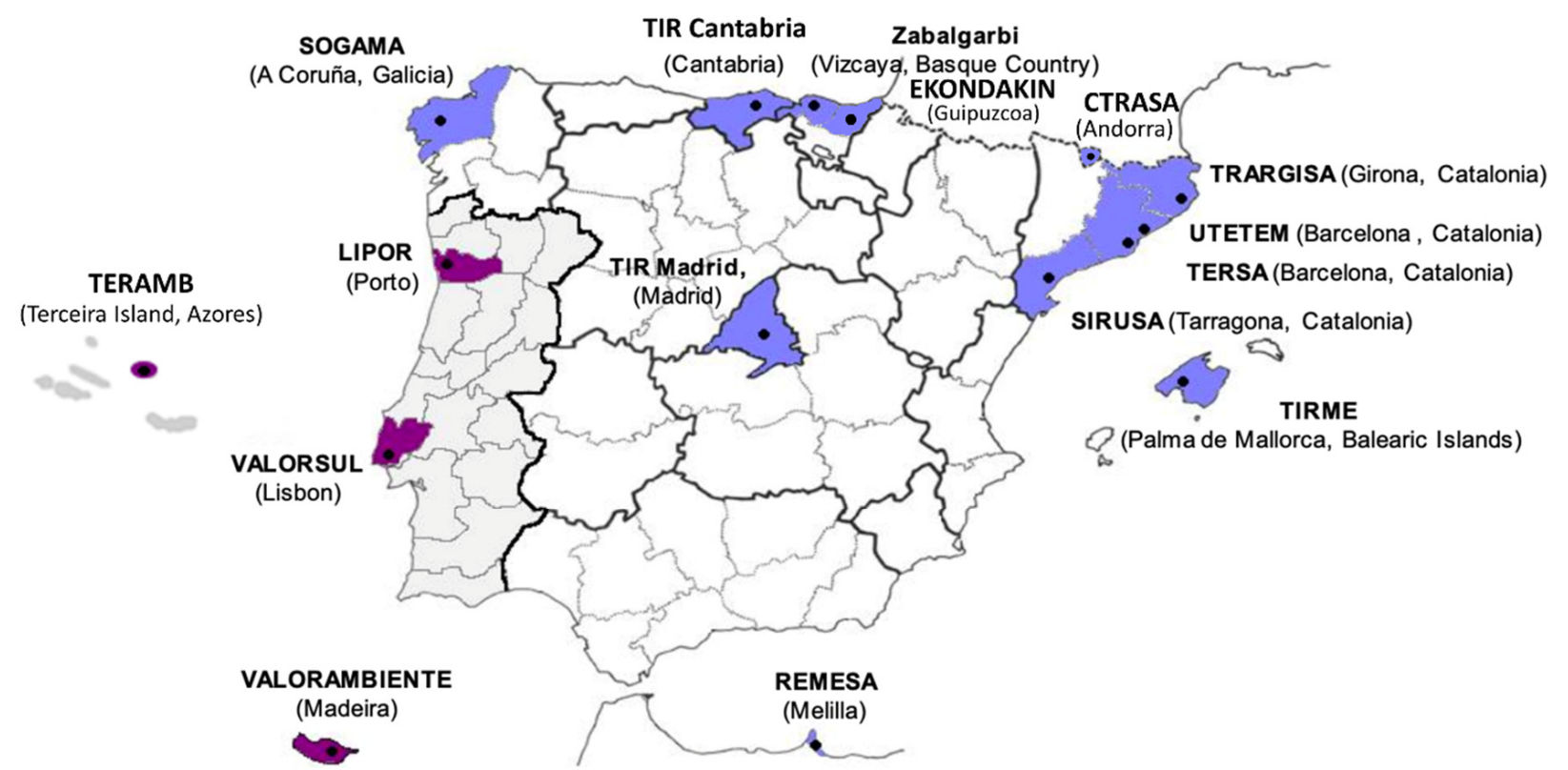

Figure 2. Location of the MSW incineration plants in the Iberian countries. Spanish facilities in light violet; Portuguese facilities in dark violet (adapted from [20]).

WtE technology has improved over the years and the modern air pollution control equipment complies with the stringent limits established for emissions in the EU Industrial Emissions Directive (Directive 2010/75/EU). The main incinerator technologies are massburn, rotary kiln and fluidized bed incineration. In mass burn (moving grate) incineration, the combustion occurs without the pre-processing of MSW apart from the exclusion of hazardous and oversized materials [21]. These incinerators display a moving grate (e.g., reciprocating grate or roller grate) for the transport of waste across the furnace, the stoking and loosening of waste, and the setting of the primary incineration area in the incineration chamber [22]. This is the most frequent design, which is used by more than $90 \%$ of European plants [23-25]. On the other hand, the rotary kiln is a very robust technology 
that can be used for nearly all waste regardless of its composition and type. This design is widely used for hazardous waste. The rotary kiln is formed by a cylindrical vessel shortly inclined on its longitudinal axis. This vessel is positioned on rollers, enabling the kiln to rotate around its axis. In these incinerators, the transport of waste occurs through the kiln due to gravity while it rotates. A secondary chamber is employed to ensure the elimination of toxic components [22]. Regarding fluidized bed incineration, the combustion occurs on a bed of inert material (e.g., sand) agitated with rising airflow through a porous plate. This design requires the pre-processing of MSW to reach a proper size (appr. 50-100 mm). The waste is then continuously fed into the fluidized bed [21]. This combustion technology improves gas-solid contact and increases energy efficiency compared to the two previous technologies.

Technical data of Portuguese and Spanish incinerators are presented in Table 1. In the Iberian countries, only moving grate incinerators and fluidized beds are applied for MSW incineration, the latter being less common. In particular, moving grate incinerators account for $82 \%$ and $100 \%$ of the incinerators in Spain and Portugal, respectively [20]. Most of the energy produced in these plants is used in the plant itself and sold to the public grid. Self-consumption energy can range between 15 to $30 \%$ of the production, depending on the pre-treatment of the MSW, the combustion technology, and the post-combustion treatments of the IBA. All the Portuguese plants recover energy as electricity, but none include combined heat and power (CHP). All the incinerators are in areas where the selective collection is implemented, and thus the calorific value of MSW may be lower for incineration due to the reduction of plastic and paper content. In Spain, although electricity is usually produced, some WtE plants produce and export thermal energy, too $(82,000 \mathrm{MWh}$ in 2019). As in Portugal, all incineration plants are in areas where the voluntary selective collection in recycling bins at the curb is implemented. In addition, in some Spanish WtE plants, a previous pre-treatment of the MSW is carried out in mechanical biological treatment (MBT) facilities. The pretreatment technology contributes to the recovery of some materials contained in the MSW and facilitates the stabilization of the biodegradable fraction. The sorting is either set to recover the individual materials (i.e., ferrous metal, non-ferrous metal, plastics, and glass) of the MSW or produce refuse-derived fuel (RDF). In this regard, there are two fluidized bed plants (SOGAMA and TIR Madrid, see Table 1) that are only fed with RDF.

Table 1. Technical data of Portuguese [26-30] and Spanish [31-35] incinerators.

\begin{tabular}{|c|c|c|c|c|c|c|}
\hline Country & Plant Location & Plant Name & $\begin{array}{l}\text { Startup } \\
\text { (Year) }\end{array}$ & $\begin{array}{c}\text { Nominal Capacity } \\
\text { (t/Year) }\end{array}$ & $\begin{array}{l}\text { Incinerator } \\
\text { Technology }\end{array}$ & $\begin{array}{c}\text { Energy Production } \\
\text { (MWh) }\end{array}$ \\
\hline \multirow{4}{*}{ Portugal } & Lisbon & Valorsul & 2000 & 662,000 & Moving grate & $361,151^{a}$ \\
\hline & Porto & LIPOR & 2000 & 380,000 & Moving grate & $188,808^{a}$ \\
\hline & \multirow{2}{*}{$\begin{array}{l}\text { Madeira Island } \\
\text { Terceira Island } \\
\text { (Azores) }\end{array}$} & ARM & 2003 & 126,000 & Moving grate & $53,206^{a}$ \\
\hline & & Teramb & 2015 & 40,000 & Moving grate & $16,035^{\mathrm{a}}$ \\
\hline \multirow{11}{*}{ Spain } & Barcelona & TERSA & 1975 & 360,000 & Moving grate & $194,742^{a}$ \\
\hline & Barcelona & UTETEM & 1994 & 160,000 & Moving grate & $85,435^{a}$ \\
\hline & Girona & TRARGISA & 1984 & 37,600 & Moving grate & $4202^{b}$ \\
\hline & Tarragona & SIRUSA & 1991 & 144,000 & Moving grate & $49,649^{a}$ \\
\hline & Cantabria & TIR Cantabria & 2006 & 96,000 & Moving grate & $87,245^{a}$ \\
\hline & Vizcaya & Zabalgarbi & 2005 & 230,000 & Moving grate & $666,233^{c}$ \\
\hline & Guipuzcoa & Ekondakin & 2020 & 200,000 & Moving grate & $160,000^{\mathrm{a}}$ \\
\hline & Coruña & SOGAMA & 2002 & 600,000 & Fluidized bed & $334,461^{a}$ \\
\hline & Madrid & TIR Madrid & 1997 & 315,000 & Fluidized bed & $228,262^{\mathrm{a}}$ \\
\hline & Melilla & REMESA & 1996 & 48,000 & Moving grate & $14,703^{a}$ \\
\hline & Mallorca Island & TIRME & 1997 & 690,000 & Moving grate & $346,905^{\mathrm{a}}$ \\
\hline Andorra & Andorra & CTRASA & 2007 & 55,000 & Moving grate & $24,855^{\mathrm{a}}$ \\
\hline
\end{tabular}

${ }^{a}$ Reference year: 2019; ${ }^{b}$ Data from 2017. It is currently undergoing expansion and improvement work; ${ }^{c}$ Combined-cycle also using natural gas. 
A schematic representation of a typical mass-burn WtE plant is depicted in Figure 3. Generally, these plants comprise a waste reception and storage system, a waste incineration furnace, an energy recovery system, and an air pollution control system. In Figure 3, the scrubber (wet, dry or semi-dry) and the bag filters are examples of air pollution control technologies that may be used for flue gas cleaning to comply with air emission limits. The IBA that remains in the furnace grate after combustion is usually water quenched and subsequently stored. This review will focus on the IBA generated in Portuguese and Spanish WtE plants.

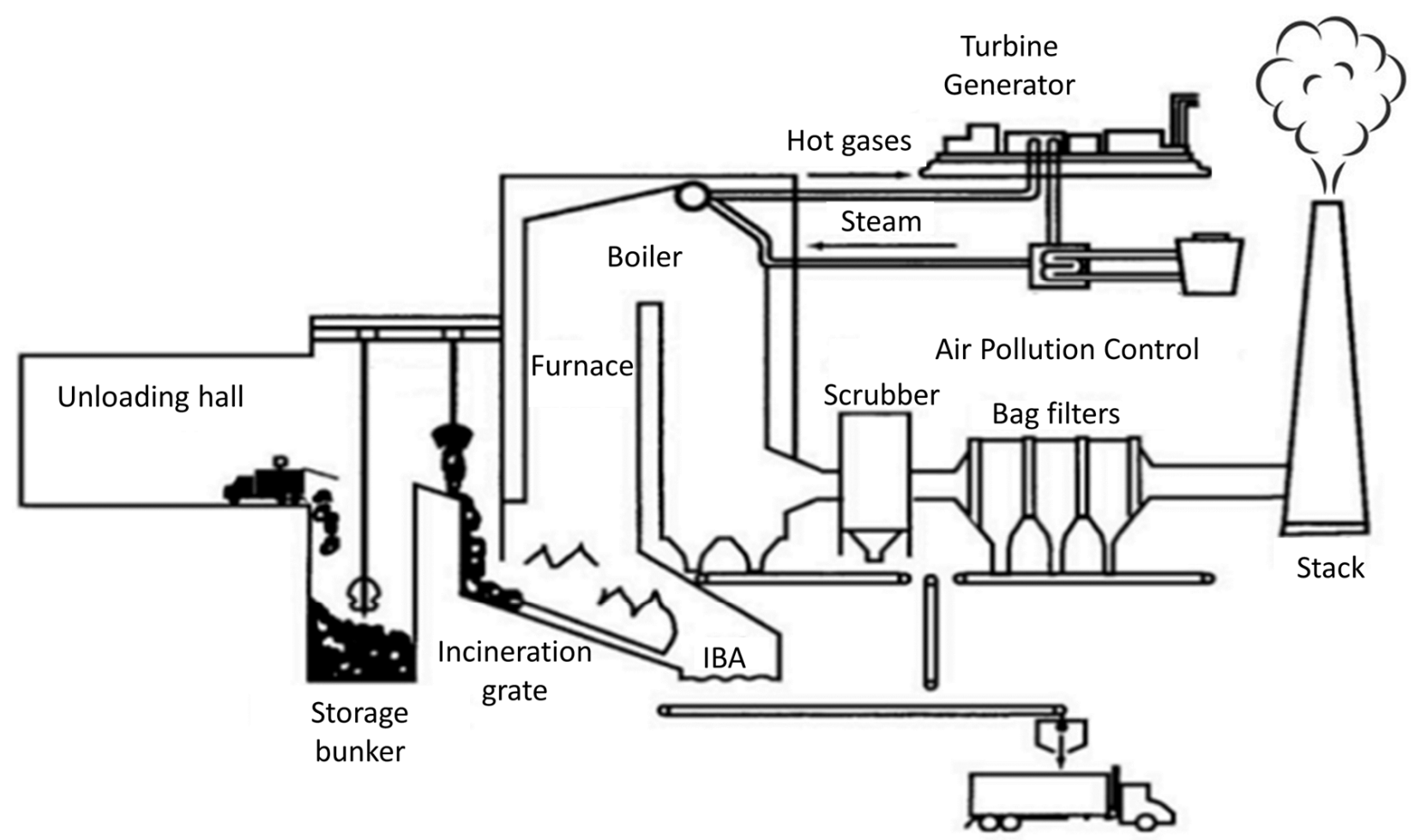

Figure 3. A schematic representation of a mass-burn WtE plant (adapted from [36]).

\section{IBA Production and Characterization}

IBA accounts for nearly $20 \mathrm{wt} . \%$ of the annual incinerated waste in Europe [15]. The four WtE plants in Portugal incinerate about $20 \mathrm{wt} . \%$ of the annual MSW and generate about $240 \mathrm{kt}$ of IBA per year, while the 12 Spanish plants (including the Andorran plant) incinerate about $16 \%$ of the MSW, generating about $474 \mathrm{kt}$ of IBA annually (Table 2). This small difference can be attributed to the fact that some of the Spanish plants carry out a previous pre-treatment of the MSW in MBT facilities, recovering a part of the noncombustible fraction of MSW (metals, glass containers, plastic containers, etc.). The MSW incinerated and the generated amounts of non-ferrous IBA and metals for recycling in two Portuguese WtE plants (LIPOR and ARM) over time, in Figure 4, show that the percentage of IBA has varied between $19 \%$ and $22 \%$ in a mainland Portuguese plant (Figure $4 \mathrm{a}$ ) and between $16 \%$ and $21 \%$ in a Portuguese island (Figure $4 \mathrm{~b}$ ). MSW started to be incinerated in Madeira Island at the end of 2003, explaining the much lower values for that year. Figure 5 depicts the MSW incinerated and IBA and metals obtained in the combustion process in two Spanish WtE plants (SOGAMA and TIRME) over time. While the former (Figure 5a) is fed with RDF obtained from MSW in an MBT facility, the second plant (Figure 5b) mainly burns MSW and a small fraction of RDF. It can be seen that the percentage of IBA generated in the fluidized bed $\mathrm{WtE}$ plant is around $12 \%$ of the MSW treated in the integral facility (MBT and WtE), while in the moving grate plant this percentage is close to $23 \%$. 


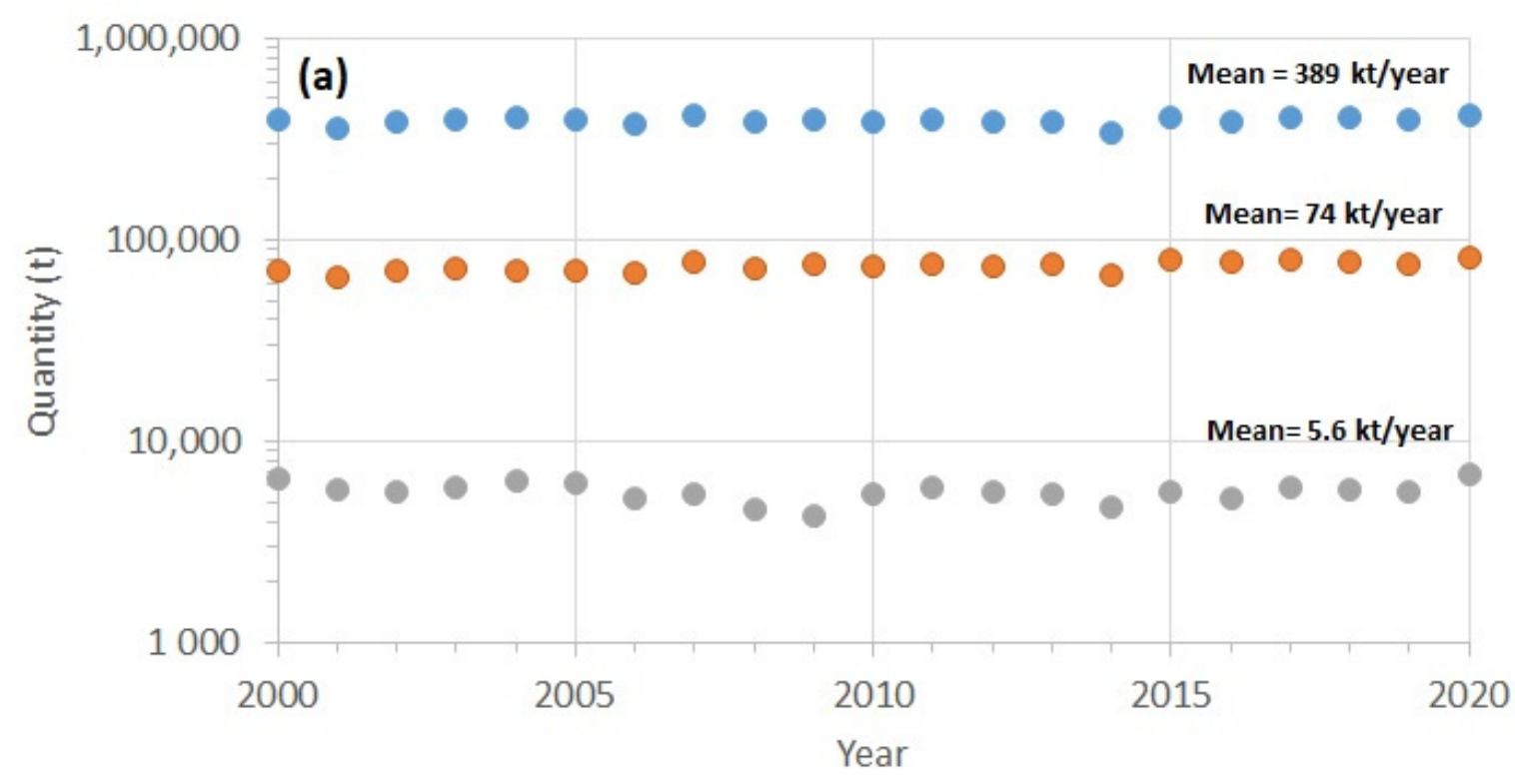

- MSW incinerated Non-ferrous IBA generated Metals for recycling

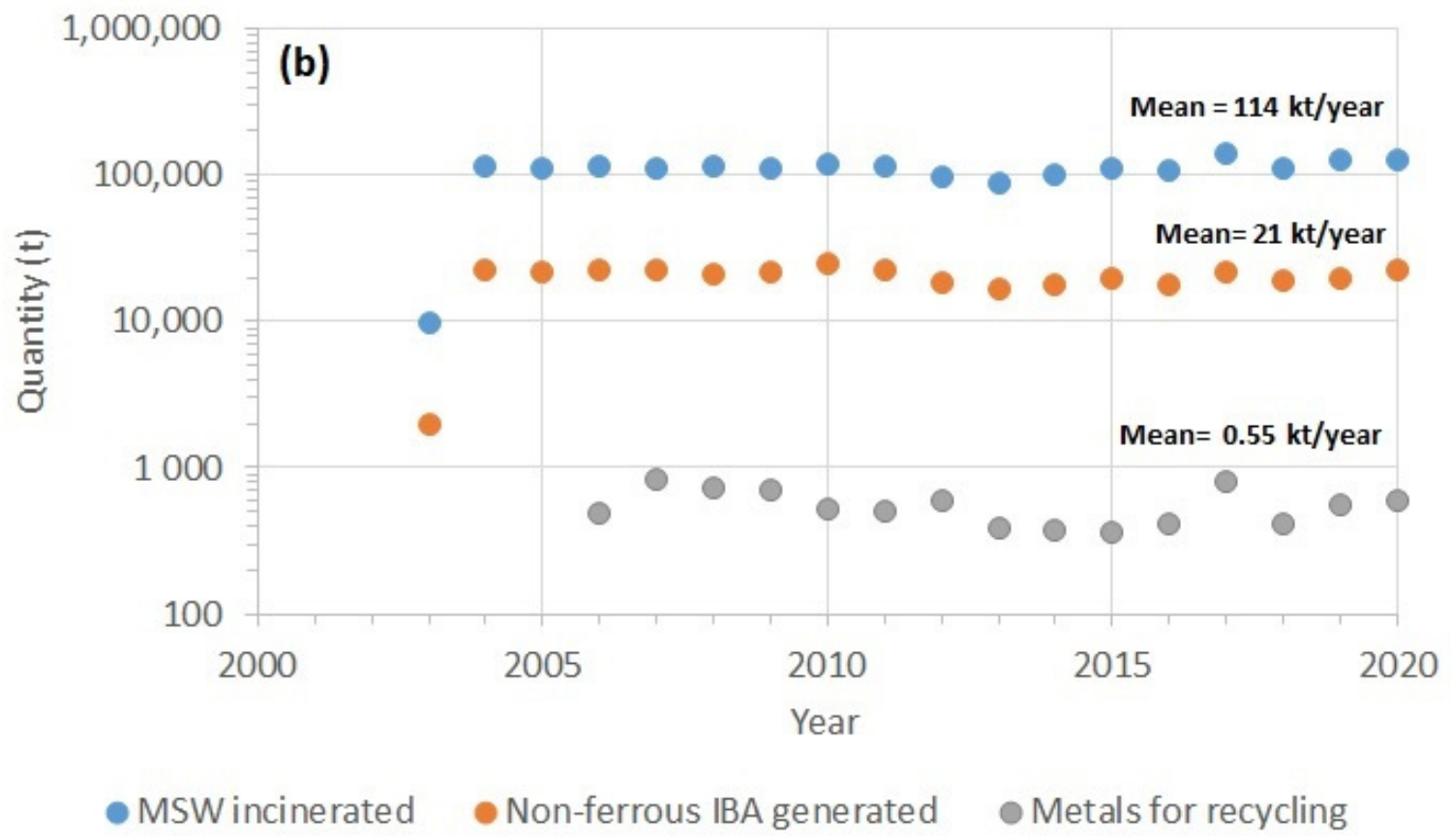

Figure 4. Incinerated and generated flows in two Portuguese WtE plants over time (a) LIPOR (in mainland Portugal) and (b) ARM (on a Portuguese island).

Accordingly, the properties of IBA depend on the composition of the MSW feedstock, the combustion technology, and the operational conditions (e.g., incineration temperature) [37]. The moisture content of IBA depends not only on the operational process conditions but also on the post-combustion treatments and storage methods [38-42]. IBA is a very heterogeneous material and contains irregularly shaped particles with a porous microstructure. Indeed, IBA is a complex mixture composed of melted products, minerals, metallic compounds, ceramics, and glass [12]. In Europe, IBA is generally composed of the material fractions presented in Figure 6. 


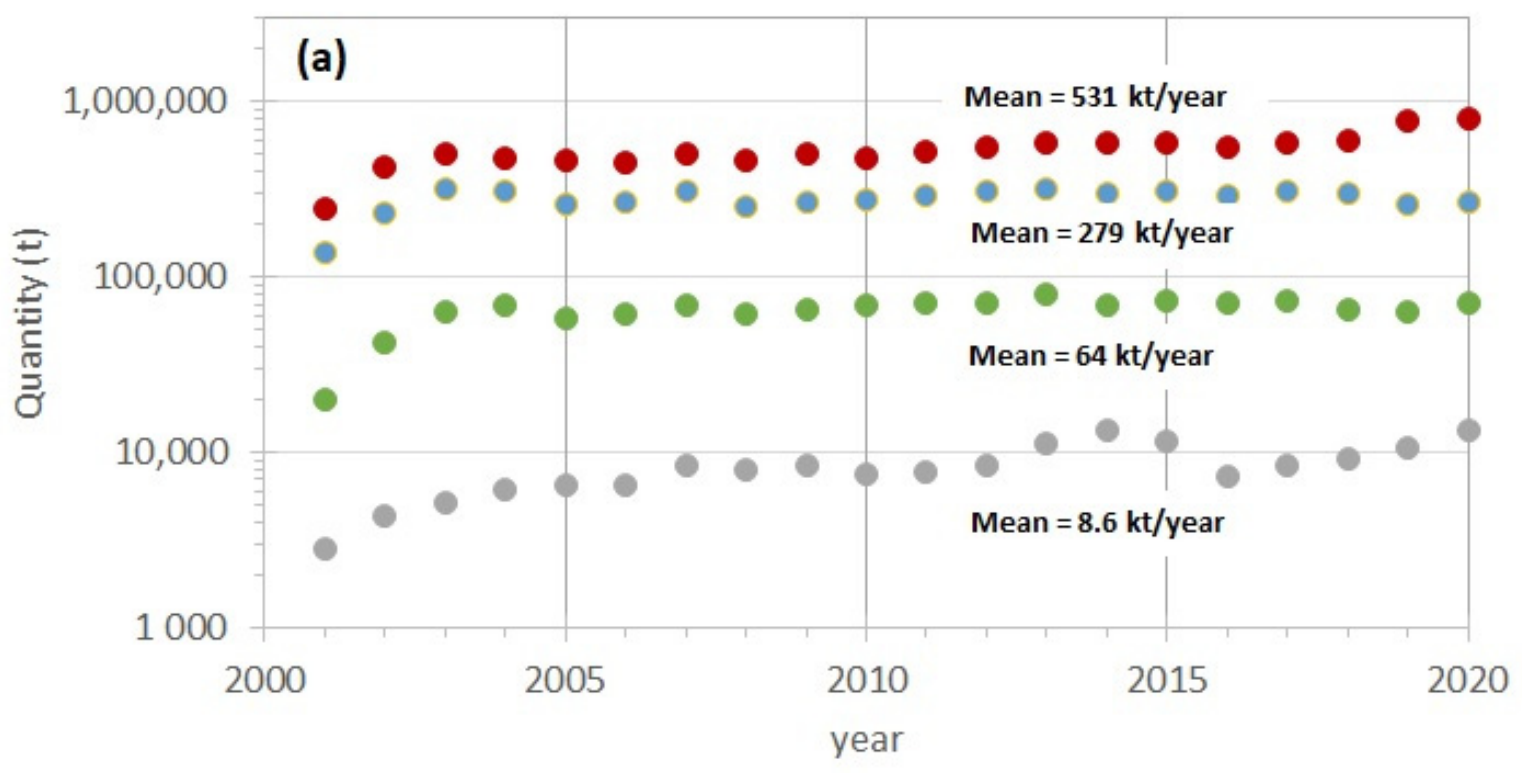

- MSW Managed - RDF Incinerated IBA generated Metals for recycling

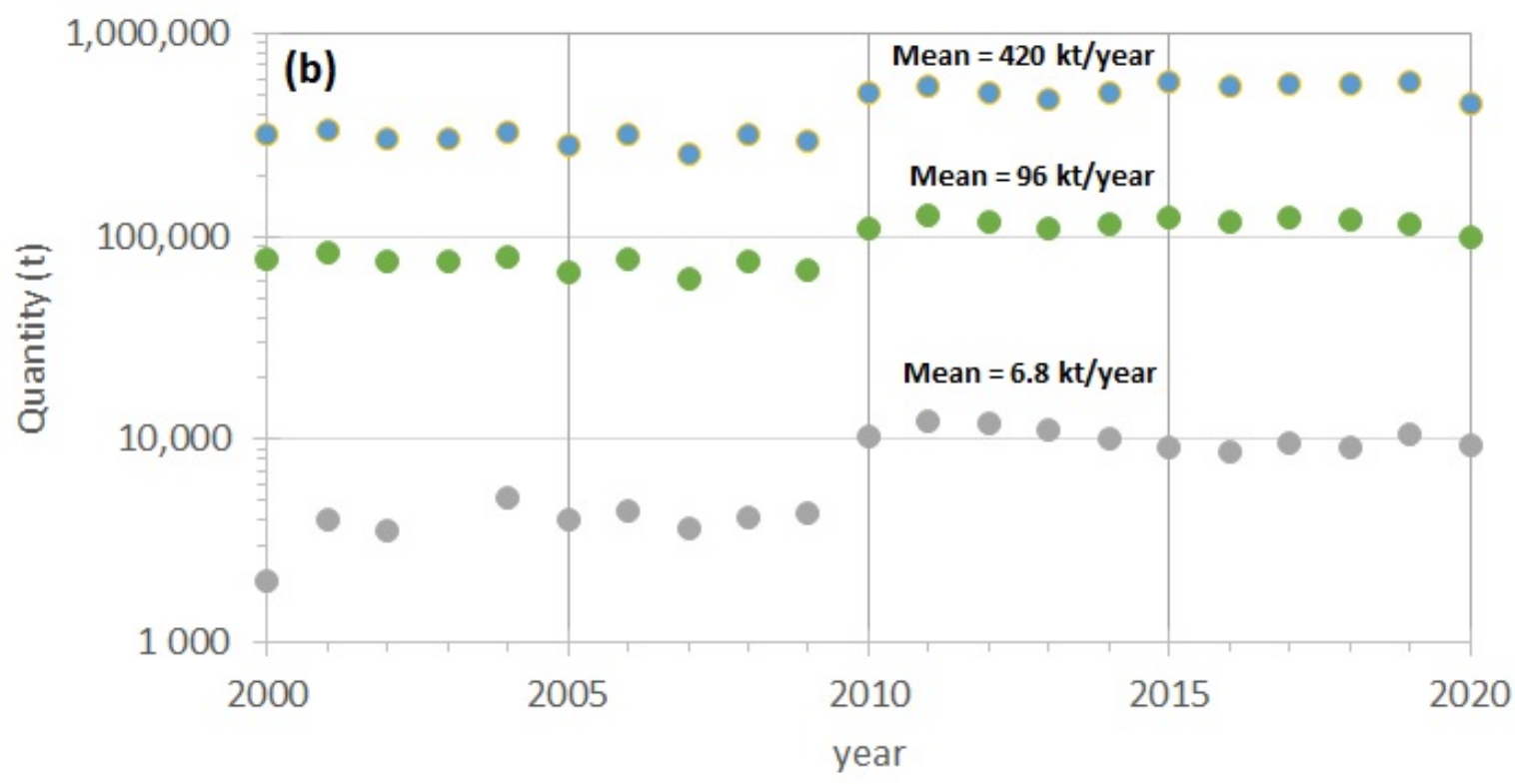

- MSW incinerated IBA generated Metals for recycling

Figure 5. Incinerated and generated flows in two Spanish WtE plants over time (a) SOGAMA and (b) TIRME. Note: in 2010 TIRME increased the number of combustion furnaces from 2 to 4 , doubling the treatment capacity.

Table 2. Amounts of IBA generated in WtE plants in Portugal ${ }^{\mathrm{a}}$ and Spain ${ }^{\mathrm{b}}$.

\begin{tabular}{|c|c|c|c|c|}
\hline \multirow{2}{*}{ Country } & \multirow{2}{*}{ Plant } & \multirow{2}{*}{ MSW Incinerated (t) } & \multicolumn{2}{|r|}{ IBA } \\
\hline & & & Metals for Recycling (t) & Non-Ferrous IBA Generated $(t)$ \\
\hline \multirow{4}{*}{ Portugal $^{\mathrm{c}}$} & Valorsul & 645,943 & 8318 & 122,242 \\
\hline & LIPOR & 389,291 & 5582 & 76,280 \\
\hline & ARM & 128,155 & 559 & 19,794 \\
\hline & Teramb & 33,250 & 143 & 7637 \\
\hline
\end{tabular}


Table 2. Cont.

\begin{tabular}{|c|c|c|c|c|}
\hline \multirow{2}{*}{ Country } & \multirow{2}{*}{ Plant } & \multirow{2}{*}{ MSW Incinerated (t) } & \multicolumn{2}{|r|}{ IBA } \\
\hline & & & Metals for Recycling (t) & Non-Ferrous IBA Generated (t) \\
\hline \multirow[t]{12}{*}{ Spain } & TERSA $^{\mathrm{c}}$ & 351,308 & 4477 & 69,163 \\
\hline & UTEEM $^{\mathrm{c}}$ & 165,756 & 222 & 30,993 \\
\hline & TRARGISA $\mathrm{d}$ & 22,003 & 610 & 5853 \\
\hline & SIRUSA $^{\mathrm{c}}$ & 140,775 & 3154 & 27,471 \\
\hline & TIR Cantabria ${ }^{c}$ & 119,813 & 2825 & 16,522 \\
\hline & Zabalgarbi & 224,591 & 2530 & 45,334 \\
\hline & Ekondakin ${ }^{\mathrm{e}}$ & 144,810 & n.d. & 32,804 \\
\hline & SOGAMA & $769,674^{f}$ & $14,660^{\mathrm{g}}$ & 70,349 \\
\hline & TIR Madrid ${ }^{c}$ & 330,290 & 5535 & 17,199 \\
\hline & REMESA & 42,673 & 592 & 9793 \\
\hline & TIRME $^{\mathrm{c}}$ & 454,734 & 9370 & 100,247 \\
\hline & CTRASA & 50,902 & 715 & 8088 \\
\hline
\end{tabular}

a $[27,43-46] ;{ }^{\mathrm{b}}$ [32-35,47,48]; ${ }^{\mathrm{c}}$ Reference year: 2019; ${ }^{\mathrm{d}}$ Data from 2017. It is currently undergoing expansion and improvement work; ${ }^{\mathrm{e}}$ There is no production data for 2019. Data is from 2020; ${ }^{\mathrm{f}}$ MSW treated in an MBT facility to obtain the RDF that feeds the WtE plant; ${ }^{\mathrm{g}}$ Separated from the MSW in the mechanical treatment before the combustion process; n.d.; not determined.

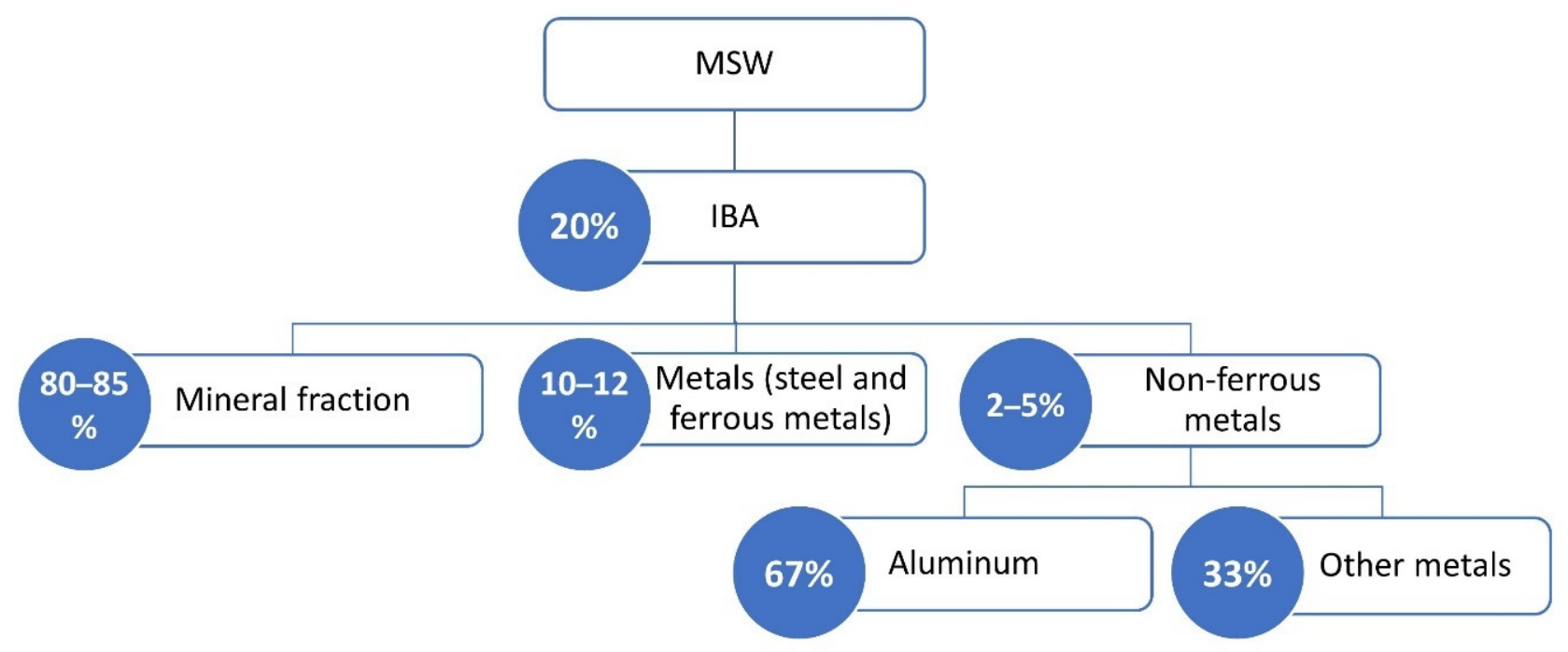

Figure 6. Fractions of IBA in Europe, according to [10].

In general, the particle size distribution of IBA covers a broad range, from a few $\mu \mathrm{m}$ to cms [49]. According to Dou et al. (2017) [13], the main fraction of IBA has a particle size between $0.02 \mathrm{~mm}$ and $10 \mathrm{~mm}$, accounting for $60-90 \mathrm{wt} . \%$. Regarding the other fractions, 5 to $15 \%$ contains particles below $0.02 \mathrm{~mm}$, while $<30 \%$ is higher than $10 \mathrm{~mm}$. The larger particles normally include construction-type materials, pieces of glass, and ferrous and non-ferrous metals. Studies on IBA from Madeira Island and Mainland Portugal have reported values in those ranges [50-52] (Figure 7a). Very similar results have been reported from the studies carried out on IBA from the SIRUSA and TERSA plants [53-55]. According to these studies, around $50 \mathrm{wt} . \%$ of IBA correspond to the $0-4 \mathrm{~mm}$ fraction, while only $25 \mathrm{wt} . \%$ of IBA have a particle size greater than $8 \mathrm{~mm}$ (Figure $7 \mathrm{~b}$ ).

While IBA's finest fraction contains most of the soluble salts and the potentially leachable heavy metal(loid)s, the coarsest fractions mainly consist of synthetic ceramics (tiles, bricks, concrete blocks) and container glass. However, it should be noted that the particle size distribution depends on the technology used (grates or fluidized bed) and on the feed to the combustion chamber (MSW or RDF). The main elements of IBA expressed as oxides are $\mathrm{SiO}_{2}, \mathrm{CaO}, \mathrm{Fe}_{2} \mathrm{O}_{3}, \mathrm{Na}_{2} \mathrm{O}, \mathrm{Al}_{2} \mathrm{O}_{3}, \mathrm{P}_{2} \mathrm{O}_{5}, \mathrm{MgO}, \mathrm{K}_{2} \mathrm{O}, \mathrm{TiO}_{2}$, and $\mathrm{SO}_{3}$, as confirmed by some Portuguese and Spanish IBA samples (Table 3). Typically, fresh IBA is alkaline with a $\mathrm{pH}$ between 10 and $13[39,56]$, and loss of ignition gives an indication of organic 
matter and eventually carbonates load. Chemical analyses of IBA from the Azores plant revealed a $\mathrm{pH}$ of 11.6 for fresh IBA and 9.2-9.7 for three-month-aged IBA, while Spanish IBA samples indicate that the $\mathrm{pH}$ of fresh IBA is around 12.5, controlled by portlandite, and the $\mathrm{pH}$ of weathered IBA after 2-3 months in the open is 10.5-11.0, controlled by calcite and ettringite, which are formed during the aging process [57]. However, $\mathrm{pH}$ can vary as a function of the particle size fractions and composition: finer fractions tend to have a higher initial content of portlandite, and in the coarser fractions portlandite is scarcer and undergoes carbonation faster [58].

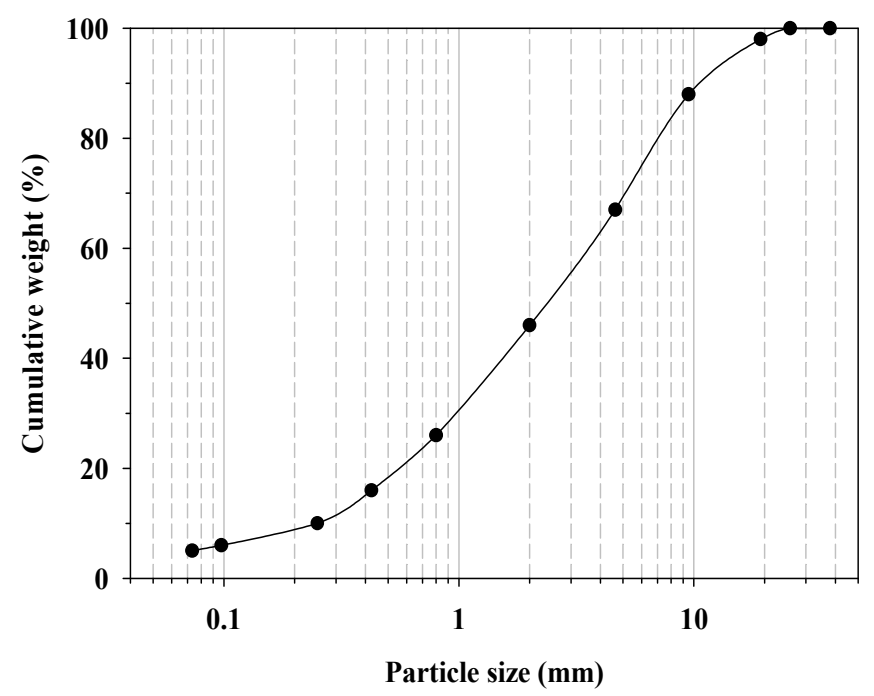

(a)

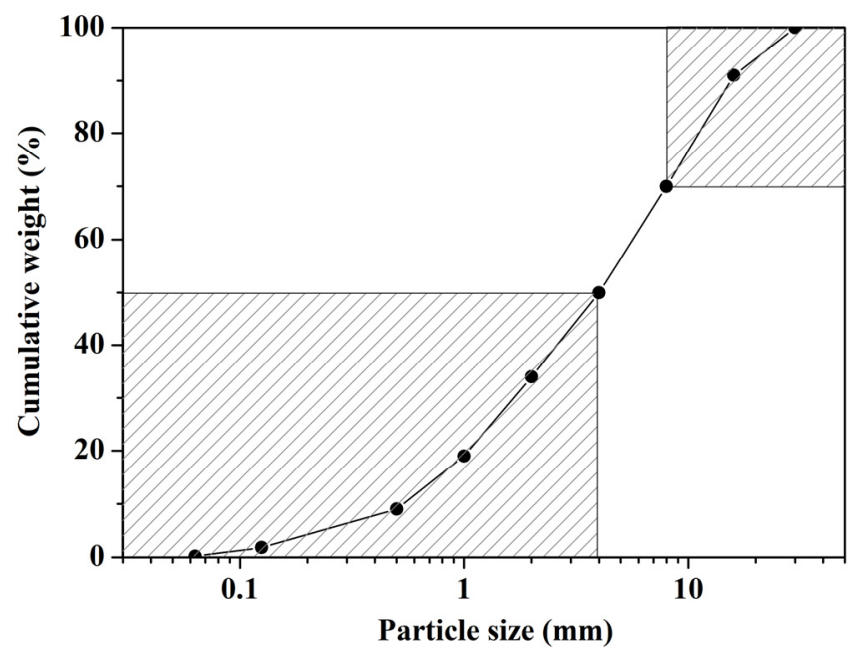

(b)

Figure 7. Particle size distribution of weathered IBA from (a) Valorsul (Lisbon, Portugal; according to [52]) and (b) SIRUSA (Tarragona, Spain).

Table 3. Chemical properties of IBA from Portuguese and Spanish WtE plants.

\begin{tabular}{|c|c|c|c|c|c|c|c|}
\hline \multirow{2}{*}{$\begin{array}{l}\text { Properties } \\
\text { (wt.\%) }\end{array}$} & \multicolumn{2}{|c|}{ [59] $^{\mathbf{a}}$} & \multirow{2}{*}{$\frac{\left[^{[60]^{b}}\right.}{\text { LIPOR }^{b}}$} & \multirow{2}{*}{$\frac{{ }^{[51]^{c}}}{\mathrm{ARM}}$} & \multirow{2}{*}{$\frac{{ }^{[55]^{\mathrm{d}}}}{\text { SIRUSA }}$} & \multirow{2}{*}{$\frac{\text { SOGAMA }(2019)^{\text {e,c }}}{\text { SOGAMA }}$} & \multirow{2}{*}{$\frac{\text { TIRME (2020) }^{\mathrm{f}}}{\text { TIRME }}$} \\
\hline & Valorsul & LIPOR & & & & & \\
\hline $\mathrm{SiO}_{2}$ & 52 & 52.2 & 43.75 & 41.75 & 45.44 & 59.21 & 22.53 \\
\hline $\mathrm{CaO}$ & 14 & 13.6 & 22.77 & 21.85 & 17.55 & 13.60 & 26.05 \\
\hline $\mathrm{Fe}_{2} \mathrm{O}_{3}$ & 6.8 & 6.8 & 2.03 & 7.26 & 6.08 & 1.24 & 6.68 \\
\hline $\mathrm{Na}_{2} \mathrm{O}$ & 6 & 3.6 & 7 & 6.01 & 5.04 & 6.83 & 2.65 \\
\hline $\mathrm{Al}_{2} \mathrm{O}_{3}$ & 5.9 & 7.7 & 6.81 & 7.94 & 10.38 & 7.49 & 21.76 \\
\hline
\end{tabular}


Table 3. Cont.

\begin{tabular}{|c|c|c|c|c|c|c|c|}
\hline \multirow{2}{*}{$\begin{array}{l}\text { Properties } \\
\text { (wt.\%) }\end{array}$} & \multicolumn{2}{|c|}{$[59]^{\mathbf{a}}$} & \multirow{2}{*}{$\begin{array}{c}\text { LI60] }^{b} \\
\text { LIPOR }\end{array}$} & \multirow{2}{*}{$\frac{{ }^{[51]^{c}}}{\mathrm{ARM}}$} & \multirow{2}{*}{$\frac{\text { [55 }^{\mathrm{d}}}{\text { SIRUSA }}$} & \multirow{2}{*}{$\frac{\text { SOGAMA (2019) }^{e, c}}{\text { SOGAMA }}$} & \multirow{2}{*}{$\begin{array}{c}\text { TIRME (2020) }^{\mathrm{f}} \\
\text { TIRME }\end{array}$} \\
\hline & Valorsul & LIPOR & & & & & \\
\hline $\mathrm{P}_{2} \mathrm{O}_{5}$ & 5.5 & 2.9 & 3.91 & 6.27 & 1.55 & 3.51 & 1.69 \\
\hline $\mathrm{MgO}$ & 2 & 3 & 5.11 & 2.59 & 2.66 & 1.79 & 2.84 \\
\hline $\mathrm{K}_{2} \mathrm{O}$ & 2 & 2.2 & 3.12 & 1.33 & 1.54 & 2.10 & 0.76 \\
\hline $\mathrm{TiO}_{2}$ & 0.5 & 0.7 & - & 1.29 & 0.65 & 0.42 & 0.54 \\
\hline $\mathrm{SO}_{3}$ & - & - & 2.43 & 1.55 & 2.57 & 1.20 & 3.59 \\
\hline $\mathrm{BaO}$ & - & - & - & 0.12 & - & 0.12 & 0.08 \\
\hline $\mathrm{CuO}$ & - & - & - & 0.2 & 0.13 & 0.16 & 0.27 \\
\hline $\mathrm{Cr}_{2} \mathrm{O}_{3}$ & - & - & - & 0.11 & - & 0.04 & 0.07 \\
\hline $\mathrm{PbO}$ & 0.35 & - & - & 0.16 & 0.11 & 0.07 & - \\
\hline $\mathrm{NiO}$ & - & - & - & 0.02 & - & 0.01 & 0.01 \\
\hline $\mathrm{ZnO}$ & 0.3 & - & 0.65 & 0.33 & 0.51 & 0.20 & - \\
\hline $\mathrm{MnO}$ & 0.1 & 0.1 & - & 0.09 & 0.03 & 0.04 & 0.08 \\
\hline $\mathrm{SrO}$ & - & - & - & 0.05 & 0.07 & 0.07 & 0.05 \\
\hline $\mathrm{SnO}_{2}$ & - & - & - & 0.04 & 0.02 & - & 0.02 \\
\hline $\mathrm{ZrO}_{2}$ & - & - & - & 0.03 & 0.03 & 0.03 & 0.02 \\
\hline $\mathrm{Cl}^{-}$ & - & - & 2.42 & 1.05 & 1.42 & 0.18 & 0.50 \\
\hline $\begin{array}{l}\text { Loss on ignition } \\
\quad\left(1000^{\circ} \mathrm{C}\right)\end{array}$ & 5.5 & 7.2 & - & - & 5.8 & 1.5 & 14.8 \\
\hline
\end{tabular}

${ }^{a}$ Particle size ranging from a few micrometers up to $10 \mathrm{~mm} ;{ }^{b}$ No information on particle size; ${ }^{c}$ Particle size ranging from $0.063 \mathrm{~mm}$ up to $16 \mathrm{~mm}$; d,f Particle size ranging from 0 to $30 \mathrm{~mm}$; ${ }^{e}$ Particle size ranging from 0 to $5 \mathrm{~mm}$ [61]. Unpublished values provided by the facility itself from its analysis.; ${ }^{\mathrm{f}}$ Particle size ranging from 0 to $30 \mathrm{~mm}$ [48]. Unpublished values provided by the facility itself from its analysis.

Potentially toxic metals such as $\mathrm{Cd}, \mathrm{Cr}, \mathrm{Cu}, \mathrm{Ni}, \mathrm{Pb}$, and $\mathrm{Zn}$ may be found in IBA (Table 3) due to their presence in MSW, and their leaching patterns may be linked to the presence of chlorides $[62,63]$. Thus, there are some environmental concerns regarding IBA $[64,65]$ related to the potential contamination of vulnerable recipient compartments, such as water bodies and groundwaters, ultimately affecting nearby biological communities [11,66-68]. However, as the chemical composition of IBA may vary significantly as a function of the particle size distribution $[39,58,64,69]$, higher concentrations of chlorides and potentially toxic metals (e.g., $\mathrm{Cr}, \mathrm{Cu}, \mathrm{Hg}, \mathrm{Mo}, \mathrm{Pb}, \mathrm{Sb}, \mathrm{Zn}$ ) have been detected for smaller IBA particles, particularly fractions under $4 \mathrm{~mm}[12,56,69-72]$.

Furthermore, most di- and trivalent potentially toxic metal(loid)s are $\mathrm{pH}$-dependent, and in natural weathering conditions the leaching potential can decrease considerably due to $\mathrm{pH}$ decrease $[57,58]$. Indeed, some of these metals can be retained in the formed mineral phases (calcite, ettringite, aluminosilicates, metal oxides, etc.). Therefore, the release of heavy metal(loid)s decreases during the aging period, and after 2-3 months in the open IBA may be classified as a non-hazardous material [57]. In fact, leaching values for weathered Portuguese and Spanish IBA have been consistently below the limits for acceptance in landfills for non-hazardous waste, according to the Portuguese Decree-Law No. 183/2009 and the Spanish Royal Decree 1481/2001 (revised by Order AAA/661/2013), respectively.

\section{Current Management of IBA}

Currently, waste classification as hazardous or non-hazardous in the EU is based on two documents: (i) Commission Decision 2000/532/EC on the European List of Waste (LoW), revised by EU Decision 2014/955/EU, and (ii) Annex III to Directive 2008/98/EC on waste (Waste Framework Directive-WFD), amended by Commission Regulation (EU) No 1357/2014. The ferrous materials that are generally recovered from IBA are an absolute entry of non-hazardous waste in the LoW with code 190102 . However, the remaining material of bottom ashes appears as a mirror entry in the LoW (codes $190111^{*}$ and 1901 12), meaning that its classification relies on the evaluation of waste properties that render it hazardous according to Regulation (EU) No 1357/2014, and on the assessment of persistent organic pollutants (POP) and corresponding concentration according to Regulation 
(EU) 2019/1021. As a result, there are different approaches for the management of IBA worldwide, particularly among the EU Member States [13,15]. IBA is commonly classified as non-hazardous $[59,73,74]$. According to the Portuguese and Spanish legislation, IBA has been classified as non-hazardous waste.

Given the large amounts of produced IBA, efforts have been made to valorize this material considering different applications instead of disposing of it in landfills. Indeed, IBA has the potential for the recovery of metals and minerals, enabling the saving of natural resources and it has been largely recycled in different countries. Ferrous and non-ferrous metals are usually recovered through magnetic separation and Eddy current separation techniques, respectively [42,75]. Nearly $80 \%$ of metals can be recovered from IBA, and metals such as aluminum, copper, steel, and zinc are frequently separated and applied as secondary raw materials [14]. The remaining ashes are generally landfilled (frequently after a solidification process with Portland cement) or used in different applications according to the policy of each country. Indeed, the rate of usage varies between $100 \mathrm{wt} . \%$ and $0 \mathrm{wt} . \%$ (i.e., $100 \mathrm{wt}$ \% disposed of in landfills) and the related regulation diverge among countries, particularly in the EU [11,13-15,49,76].

Before reuse, different treatments may be applied to reduce the potential mobility of potentially hazardous constituents from IBA. Depending on the intended IBA application, these treatments may include natural weathering, washing, heat treatment, particle densitybased separation, and stabilization with the addition of hydraulic binders [11,77]. Natural weathering is the most commonly used treatment. In this case, IBA is stored outdoors and exposed to ambient conditions for 6 to 20 weeks to undergo an aging/weathering process $[14,55]$. This results in the neoformation and hydration of the mineral phases involving carbonation and oxidation reactions, which leads to a $\mathrm{pH}$ reduction to the range of 8-10 [55,57]. The reactions of hydration originate mineral species that can encapsulate some potentially toxic metals, leading to an enhanced leaching behavior [11,78-84].

There are several potential applications of IBA. The replacement of aggregates has been an appealing use for IBA due to its geotechnical properties [13]. Many European countries apply IBA as a secondary raw material to replace natural materials (e.g., gravel and sand). Belgium, Denmark, France, Germany, the Netherlands, the United Kingdom, and, in particular, Portugal and Spain use IBA in road construction. IBA has also been applied in acoustic barriers for roads in Germany and the Netherlands [14]. Other common functions involve cement production [40,85], as aggregate for concrete [14,40,86,87], embankments [88], and as landfill cover [13,14]. Furthermore, novel applications have been explored for this material. For example, its use as a precursor for alkali-activated binders, as adsorbent material to remove contaminants from wastewater and landfill gases, and as raw material for the production of ceramic-based products $[40,59,89,90]$.

EU countries have established individual rules with different requirements for the utilization of the mineral fraction of IBA. In this context, appropriate classification of this material can play a key role in future utilization. In the EU, waste incineration is regulated by Directive 2010/75/EU on industrial emissions. This directive sets out that the incineration residues must be recycled as appropriate, and their amount and harmfulness must be minimized. Somewhat conversely, a fraction of IBA is still being landfilled (after a stabilization treatment) in the Iberian countries (Figure 8). However, Portuguese and Spanish IBA has also been used in landfills as a substitute for soil for the intermediate and final cover, construction of paths, accesses, and platforms at the landfill level. The metal recovery for recycling has been continuously carried out in WtE plants from Portugal, amounting to 14,602 kt (mostly ferrous metals) in 2019 (Table 2). Ferrous metals are nearly recovered in total $(100 \%)$, while only one plant recovers non-ferrous metals (Valorsul) contained in the IBA (around 70\%) [44,91-93]. In Spain, all the WtE plants are equipped with devices for the recovery of ferrous metals from fresh IBA, amounting to $40.2 \mathrm{kt}$ in 2019 (Table 2), all of it recycled into the steel industry. Furthermore, in Spain, those WtE plants that obtain a conditioned IBA for use as secondary material (TIRME, SIRUSA, UTEEM, TERSA), in addition to continuing to recover ferrous metals through magnetic separators, 
also recover non-ferrous metals through Eddy current devices, this fraction being around $1-3 \%$ of the conditioned IBA $[33,48,54]$.

(a)
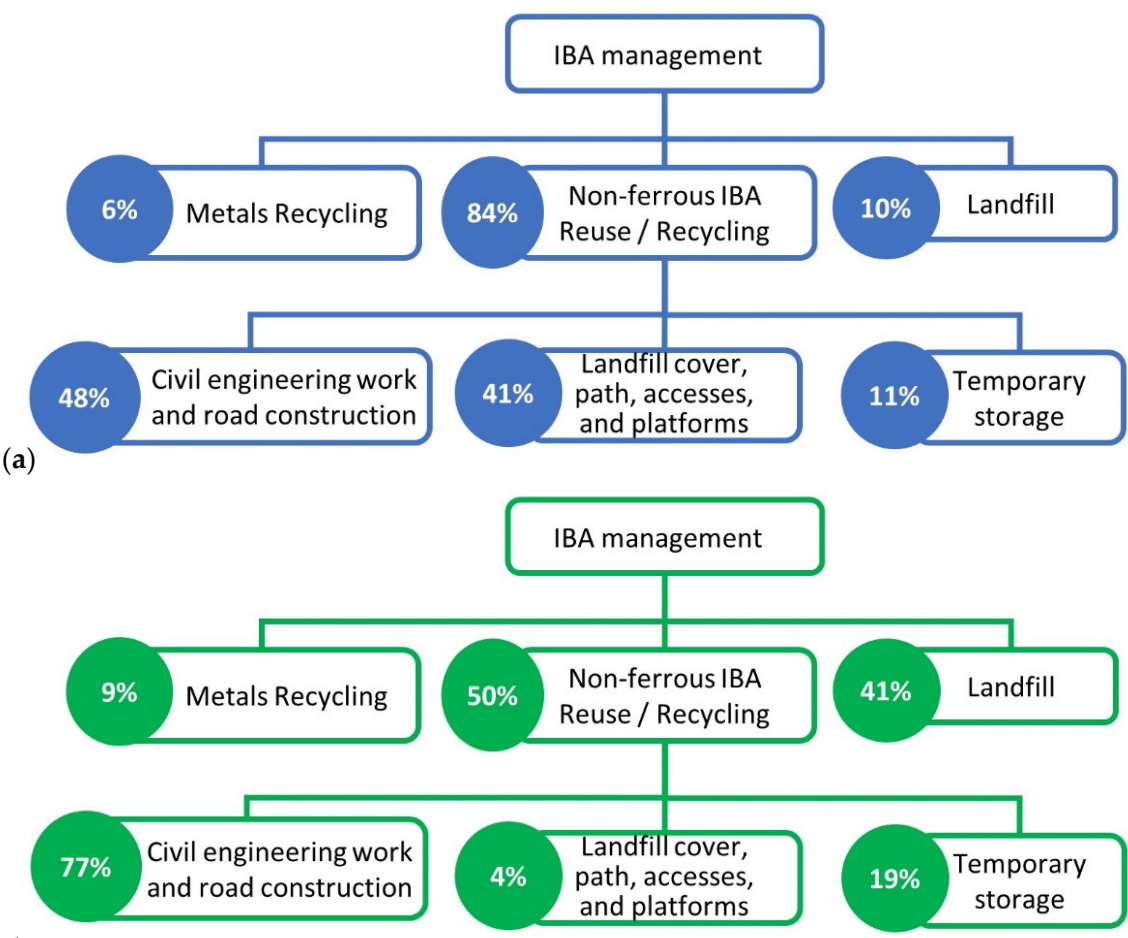

(b)

Figure 8. IBA management in (a) Portugal (reference year: 2019) and (b) Spain and Andorra (reference year: 2019).

According to Blasenbauer et al. (2020) [15], 16 out of 22 EU countries (plus Norway and Switzerland) allow the utilization of mineral IBA outside landfills. However, only 11 of them use it, at a rate varying from 20 to $100 \mathrm{wt} . \%$. These include the Iberian countries under specific requirements (Table 4). In Portugal, mineral IBA utilization outside landfills is permitted and practiced under an individual permit issued by LNEC (Laboratório Nacional de Engenharia Civil-National Civil Engineering Laboratory) to one processing plant (Valorsul). There are no specific parameters defined for Portuguese IBA and total elemental content is not considered. Instead, the requirement is compliance with leaching limit values for Portuguese non-hazardous waste landfill defined in the Portuguese Decree-Law No. 183/2009. Additionally, NP EN 13242:2002 + A1:2010 regulates the use as aggregates for unbound and hydraulically bound materials in road construction and civil engineering work. Currently, Valorsul produces aggregates from IBA in a dedicated plant with a capacity of 200 thousand tons per year. The material can be used in earthmoving works (landfills and pavement beds), in layers/sub-base layers of roads, and as filling material for landscape recovery of quarries or open-pit mines. The treatment process consists of the weathering of IBA (at least three months), removal of coarse elements, and extraction of ferrous and non-ferrous metals. The produced aggregate has a maximum nominal size of $31.5 \mathrm{~mm}$ and continuous granulometry. The aggregate obtained the EC certificate of compliance with the harmonized standard EN 13242, establishing the criteria for that specific application. Table 5 shows the requirements for valorizing IBA outside landfills in Portugal and the values obtained in the analysis for the EC marking. In this analysis, all the measured values were below the thresholds. In 2019, 94,770 kt of artificial aggregate were produced, representing an increase of $28 \%$ compared to 2018 [46]. 
Table 4. Information on mineral IBA utilization outside landfills and corresponding requirements in Portugal (PT) and Spain (ES).

\begin{tabular}{|c|c|c|c|c|c|c|c|c|c|}
\hline Country & $\begin{array}{c}\text { Use } \\
\text { Authorized }\end{array}$ & $\begin{array}{c}\text { Use Rate } \\
\text { Outside } \\
\text { Landfills } \\
\text { (wt.\%) }\end{array}$ & $\begin{array}{c}\text { National Use } \\
\text { Rate Outside } \\
\text { Landfills } \\
\text { (wt.\%) }\end{array}$ & $\begin{array}{c}\text { Document } \\
\text { Regulating Use } \\
\text { Outside Landfills }\end{array}$ & $\begin{array}{c}\text { Permitted } \\
\text { Application } \\
\text { Outside Landfills }\end{array}$ & $\begin{array}{l}\text { Specific } \\
\text { Criteria } \\
\text { for IBA }\end{array}$ & $\begin{array}{l}\text { Requirements } \\
\text { on the Total } \\
\text { Content }\end{array}$ & $\begin{array}{l}\text { Requirements on } \\
\text { Leaching Content }\end{array}$ & $\begin{array}{c}\text { Other } \\
\text { Requirements }\end{array}$ \\
\hline \multirow[t]{2}{*}{ ES } & $\begin{array}{c}\text { Catalonia and } \\
\text { Cantabria } \\
\text { (autonomous } \\
\text { communities) }\end{array}$ & $88^{f}$ & $38^{g, h}$ & $\begin{array}{c}\text { Legislation }^{\mathrm{i}} \text { : Ordre } \\
\text { de } 15 \text { de febrer de } \\
\text { 1996, sobre } \\
\text { valorització } \\
\text { d'escóries, } \\
\text { (Catalonia) }\end{array}$ & $\begin{array}{l}\text { Road subbase, } \\
\text { leveling of terrain } \\
\text { and embankments, } \\
\text { filling, and } \\
\text { restoration of } \\
\text { degradable areas } \\
\text { from extractive } \\
\text { activities, others. }\end{array}$ & Yes & $\begin{array}{c}\text { Loss on ignition, } \\
\text { unburnt } \\
\text { material }\end{array}$ & $\begin{array}{c}\text { As, } \mathrm{Cd}, \mathrm{Cr}(\mathrm{VI}), \mathrm{Cu}, \\
\mathrm{Pb}, \mathrm{Zn} \text {, total } \\
\text { dissolved solids }\end{array}$ & No \\
\hline & & & & $\begin{array}{c}\text { Legislation } \mathrm{j} \text { : } \\
\text { Decreto } 100 / 2018, \\
\text { de } 20 \text { de diciembre, } \\
\text { de valorización de } \\
\text { escorias (Cantabria) }\end{array}$ & $\begin{array}{l}\text { Cantabria: road } \\
\text { construction and } \\
\text { formulation } \\
\text { of concrete. }\end{array}$ & Yes & No & $\begin{array}{c}\text { As, } \mathrm{Ba}, \mathrm{Cd}, \mathrm{Cu}, \mathrm{Cr} \\
\text { (total), } \mathrm{Hg}, \mathrm{Ni}, \mathrm{Pb}, \mathrm{Zn} \text {, } \\
\mathrm{Mo}, \mathrm{Se}, \text { chloride, } \\
\text { fluoride, sulfate, } \\
\text { dissolved organic } \\
\text { carbon, total } \\
\text { dissolved solids }\end{array}$ & $\begin{array}{l}\text { Compliance with } \\
\text { Pliego de } \\
\text { Prescipciones } \\
\text { Técnicas Generales } \\
\text { para obras de } \\
\text { carreteras y } \\
\text { puentes, PG-3 }\end{array}$ \\
\hline
\end{tabular}

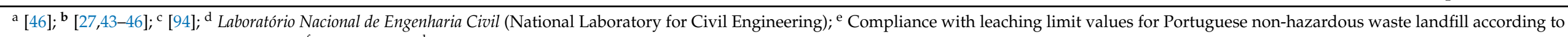

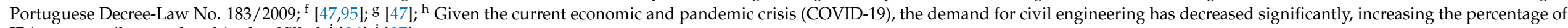
IBA temporarily stored and/or landfilled; ${ }^{i}[96] ;{ }^{j}[97]$. 
Table 5. Values of the leaching analysis to obtain EC marking for IBA aggregates from a Portuguese processing plant (Valorsul) and the requirements for valorizing IBA outside landfills based on limit values for non-hazardous waste according to the Portuguese Decree-Law No. 183/2009 (L/S = 10 L/kg) (adapted from LNEC, 2015 [94]).

\begin{tabular}{|c|c|c|}
\hline Parameters & Leaching Content & $\begin{array}{l}\text { Limit Values for Landfills of } \\
\text { Non-Hazardous Waste }\end{array}$ \\
\hline Total Moisture (\%) & 12 & - \\
\hline $\mathrm{pH}$ & 9.9 & - \\
\hline TDS (mg/kg) & 12,293 & 60,000 \\
\hline $\mathrm{DOC}(\mathrm{mg} / \mathrm{kg})^{a}$ & 869 & $1000^{b}$ \\
\hline Chlorides $(\mathrm{mg} / \mathrm{kg})^{\mathrm{c}}$ & 3082 & 50,000 \\
\hline Fluorides (mg/kg) & 20 & 250 \\
\hline Sulphates $(\mathrm{mg} / \mathrm{kg})^{\mathrm{c}}$ & 2172 & 20,000 \\
\hline As $(\mathrm{mg} / \mathrm{kg})$ & $<0.02$ & 5.0 \\
\hline $\mathrm{Ba}(\mathrm{mg} / \mathrm{kg})$ & 1.04 & 100 \\
\hline $\mathrm{Cd}(\mathrm{mg} / \mathrm{kg})$ & $<0.02$ & 2.0 \\
\hline $\mathrm{Cr}(\mathrm{mg} / \mathrm{kg})$ & $<0.08$ & 20 \\
\hline $\mathrm{Cu}(\mathrm{mg} / \mathrm{kg})$ & 7.8 & 50 \\
\hline $\mathrm{Hg}(\mathrm{mg} / \mathrm{kg})$ & $<0.01$ & 0.5 \\
\hline Mo $(\mathrm{mg}(\mathrm{kg})$ & 0.67 & 10 \\
\hline $\mathrm{Ni}(\mathrm{mg} / \mathrm{kg})$ & 0.15 & 10 \\
\hline $\mathrm{Pb}(\mathrm{mg} / \mathrm{kg})$ & $<0.13$ & 10 \\
\hline $\mathrm{Sb}(\mathrm{mg} / \mathrm{kg})$ & 0.39 & 0.7 \\
\hline Se $(\mathrm{mg} / \mathrm{kg})$ & $<0.04$ & 0.5 \\
\hline $\mathrm{Zn}(\mathrm{mg} / \mathrm{kg})$ & 0.49 & 50 \\
\hline
\end{tabular}

${ }^{a}$ Dissolved organic carbon (DOC). ${ }^{b}$ Provided that the landfill is specially intended for the admission of organic waste, this value may be exceeded; it may also be exceeded as long as the residue is not susceptible to fermentation.

c The values of total dissolved solids (TDS) can be used as an alternative to the values for sulfates and chlorides.

On the other hand, in Spain, each autonomous community has its own environmental authority, and these can regulate and limit the use of IBA as a secondary material. Thus, the use of IBA is uneven across the territory, and while some communities use it as a secondary material, others manage it in landfills. In this context, since 1996, Catalonia has been regulating the use of IBA as a secondary material. In this case, IBA utilization is based on legislation defined specifically for that material [96], considering requirements both on total content and leaching content. Thus, the use of IBA outside landfills is permitted in the field of road subbase, leveling of terrain and embankments, filling, and restoration of degradable areas from extractive activities, and others. Before its reuse, fresh IBA is processed in a conditioning plant for the recovery of ferrous and non-ferrous metals, using electromagnets and Eddy current separators, respectively, and removing light materials (papers, plastic pieces, etc.), obtaining a homogenized granular material. After homogenization, the fresh IBA is stabilized for 2-3 months in the open (natural weathering) obtaining a secondary aggregate with a particle size of $0-30 \mathrm{~mm}$. Table 6 shows the requirements for valorizing IBA outside landfills in Catalonia (Spain) obtained from a sample as received (s.m.t.q.), the dry sample (s.m.s), and from a leachate obtained according to standard DIN 38414-4 (at present EN 12457-4). Apart from the values obtained from the sample, there are other requirements described in the regulations for the reuse of the IBA:

- It will not be used in flood areas.

- It will not be used within $30 \mathrm{~cm}$ of rivers or streams.

- It will not be used on land that has its water paddock less than $5 \mathrm{~m}$ from the surface of the soil.

- It will not be used within $100 \mathrm{~m}$ of any operation of groundwater for the supply of drinking water to populations. If there are supply wells within its radius of influence that may be affected, a study of its power behavior must be studied for its authorization.

- It cannot be used in areas with significant thicknesses of the following materials: 
- Consolidated materials with high permeability due to intense cracking.

- Non-consolidated porous materials such as current alluvial deposits and current coastal plains, terraces, and old alluvial deposits, which are not cemented.

- Layers of surface alteration of materials originally permeable.

- It can only be used as a sub-base of roads when the slag layer used does not exceed a thickness of $50 \mathrm{~cm}$ and if the road has an asphalt surface layer on its surface.

- It may only be used for leveling of terrain and embankments if it is applied in layers of a thickness of $1 \mathrm{~m}$ on average for every $1000 \mathrm{~m}^{2}$ of extension without exceeding in any circumstances the layer of slag $2 \mathrm{~m}$ height and provided that the surface is then covered with densely compacted material.

- It may only be used for filling and restoration of degradable areas from extractive activities only if it is a filling on clay soils or restoration of clay extractions. In any case, it will be necessary to make a suitable sealing of the surface and drainage of rainwater.

Table 6. Parameters and limit values for valorizing IBA in Catalonia (Spain), according to the Ordre de 15 de febrer de 1996, sobre valorització d'escóries, and Cantabria (Spain), according to Decreto 100/2018 de 20 de diciembre, de valorización de escorias.

\begin{tabular}{|c|c|c|c|c|}
\hline & Parameters & $\begin{array}{l}\text { Typical } \\
\text { Content }\end{array}$ & $\begin{array}{l}\text { Limit Values for Valorizing } \\
\text { IBA (Catalonia) }^{b}\end{array}$ & $\begin{array}{l}\text { Limit Values for Valorizing } \\
\text { IBA (Cantabria) }\end{array}$ \\
\hline \multirow[t]{3}{*}{ Solid IBA (s.m.t.q.) $^{\mathrm{c}}$} & Soluble fraction $(\%)$ & $0.8-1.15$ & 3 & - \\
\hline & $\begin{array}{l}\text { Loss on ignition between } \\
500 \text { and } 105^{\circ} \mathrm{C}(\%)\end{array}$ & $3.9-5.9$ & 5 & - \\
\hline & Unburned matter (\%) & $1.6-2.5$ & 5 & - \\
\hline \multicolumn{5}{|l|}{ Leachate $^{a}$} \\
\hline & As (mg/kg) & $<0.02-0.03$ & 1 & 0.5 \\
\hline & $\mathrm{Ba}(\mathrm{mg} / \mathrm{kg})$ & $0.42-0.6$ & - & 20 \\
\hline & $\mathrm{Cd}(\mathrm{mg} / \mathrm{kg})$ & $<0.01-0.04$ & 1 & 0.04 \\
\hline & $\mathrm{Cu}(\mathrm{mg} / \mathrm{kg})$ & $1.9-5.2$ & 20 & 2 \\
\hline & Cr VI (mg/kg) & $0.05-0.2$ & 1 & \\
\hline & Cr total $(\mathrm{mg} / \mathrm{kg})$ & $0.1-0.4$ & - & 0.5 \\
\hline & $\mathrm{Hg}(\mathrm{mg} / \mathrm{kg})$ & $<0.05$ & - & 0.01 \\
\hline & $\mathrm{Ni}(\mathrm{mg} / \mathrm{kg})$ & $0.1-0.03$ & - & 0.4 \\
\hline & $\mathrm{Pb}(\mathrm{mg} / \mathrm{kg})$ & $0.08-0.5$ & 5 & 0.5 \\
\hline & $\mathrm{Zn}(\mathrm{mg} / \mathrm{kg})$ & $0.9-1.7$ & 20 & 4 \\
\hline & Mo (mg/kg) & $0.3-0.7$ & - & 0.5 \\
\hline & Se $(\mathrm{mg} / \mathrm{kg})$ & $<0.05$ & - & 0.1 \\
\hline & $\mathrm{Sb}(\mathrm{mg} / \mathrm{kg})$ & $0.05-0.4$ & - & 0.06 \\
\hline & Chlorides $(\mathrm{mg} / \mathrm{kg})$ & $120-18,000$ & - & 800 \\
\hline & Fluorides $(\mathrm{mg} / \mathrm{kg})$ & $0.2-2.0$ & - & 10 \\
\hline & Sulphates $(\mathrm{mg} / \mathrm{kg})$ & 250-2000 & - & 1000 \\
\hline & TDS $(\mathrm{mg} / \mathrm{kg})$ & $4000-6000$ & - & 4000 \\
\hline & DOC (mg/kg) & 20-50 & - & 500 \\
\hline & Phenol index & $<0.01$ & - & 1 \\
\hline
\end{tabular}

${ }^{\mathrm{a}}$ Leaching of weathered IBA in Catalonia according to the leaching standard DIN 38414-S4 * $(\mathrm{L} / \mathrm{S}=10 \mathrm{~L} / \mathrm{kg}) .{ }^{*}$ At present: ${ }^{\mathrm{b}}$ EN $12457-4$. The $\mathrm{L} / \mathrm{S}$ ratio has been taken into account to convert the units from $\mathrm{mg} \cdot \mathrm{L}^{-1}$ to $\mathrm{mg} \cdot \mathrm{kg}^{-1}$. ${ }^{c}$ Obtained from the sample as received (s.m.t.q.).

More recently, the autonomous community of Cantabria (northern Spain) has also legislated on the use of IBA as a secondary material [97]. In this case, in addition to the environmental requirements based on the EN-12457-4 leaching test (Table 6), the autonomous community of Cantabria restricts the use of IBA only as secondary aggregates in road construction (layers with a thickness lower than $0.7 \mathrm{~m}$ ) and concrete formulation, in compliance with the technical requirements. As shown in Table 6, the environmental requirements between the two autonomous communities, determined from leachates obtained from dynamic leaching tests, differ greatly. While Cantabria establishes the limits for inert waste, in Catalonia the limits are between inert and non-hazardous waste, corresponding to the classification of waste managed in landfills. 


\section{Potential Drivers, Barriers, and Prospects for IBA Use}

Globally, the demand for natural resources has been widely increasing in recent decades, causing environmental pressure. It is estimated that, without new policies, the global use of resources will grow from 89,000 Mt in 2017 to 167,000 Mt in 2060 [98]. Particularly for aggregates, the consumption in western countries plays a major role in the exploitation of non-renewable natural resources, and the annual production of aggregates is about $2500 \mathrm{Mt}$ at the EU level [99]. In the EU, there has been a growing concern for using wastes as resources towards a circular economy approach in which natural resources must be managed in a sustainable manner [100]. In fact, one of the objectives of the European Green Deal presented by the European Commission is to enhance the efficient use of resources through the shift to a circular economy paradigm [101]. In particular, since high amounts of IBA have been generated in the EU (and other countries with incineration), it seems very relevant to find solutions to manage it in a sustainable manner. As noted above, the utilization of IBA has been studied and applied to substitute raw materials. According to Valorsul (2021b) [99], the artificial aggregate produced with IBA can be used in the framework of the Portuguese Decree-Law No. 178/2006 establishing that, whenever technically feasible, at least $5 \%$ of recycled materials or those that incorporate recycled materials must be used in public construction works. Moreover, the use of IBA in landfill cover makes it possible to avoid the extraction of soil for the purpose, greatly avoiding the associated environmental impacts linked to the consumption of natural (finite) resources, their transportation, and the consequences of the extraction on vegetation, fauna, water quality, landscape, etc.

The European Green Deal also intends to restore/protect biodiversity and cut down on pollution [101]. According to the waste management hierarchy established by the WFD for the EU member states, disposal in landfills should be the last option for waste management. Diverting waste from landfills must be a priority due to inherent constraints, namely extended aftercare periods, limited landfill space, and high potential environmental impacts, e.g., emissions of greenhouse gases $\left(\mathrm{CH}_{4}\right.$ and $\left.\mathrm{CO}_{2}\right)$, pollution of groundwater and soil, odor emission, and loss of potentially recyclable resources $[10,11,59,102]$. Proper and environmentally sound utilization of anthropogenic resources like IBA contributes both to the circular economy and the reduction of the amount of waste landfilled and related impacts. Furthermore, diverting waste from landfills provides economic benefits, since landfill costs, taxes, and costs of mining raw materials are prevented [103]. According to Blasenbauer et al. (2020) [15], the use of the mineral fraction of IBA could reduce the volume of non-hazardous waste landfills in the EU by 5 million $\mathrm{m}^{3}$ or $7-8 v / v \%$ annually.

However, "waste" classification leads to constrictions on its management and utilization. The development of "end-of-waste" criteria according to Article 6 of the WFD could be relevant, possibly favoring reuse. This status is presented in the WFD for certain specified waste that is subjected to a recovery operation (including recycling) and complies with certain criteria for becoming a product, including (i) the common use for specific purposes, (ii) the existence of a market or demand, (iii) the fulfillment of the technical requirements for the specific purposes and the compliance with legislation and standards, and (iv) the avoidance of overall adverse environmental or human health impacts. This status may be given at the EU or national level or be considered case by case within EU member states. There have been complex discussions in the EU on how to comply with the WFD conditions, especially those linked to the protection of human health and the environment. As a result, the status has not been achieved yet at the EU level. Moreover, none of the EU member states has yet established national criteria for IBA $[15,104]$. A potential end-of-waste status should not result in the assumption that no further assessment of IBA properties is necessary. In fact, testing is essential to confidently appraise the environmental behavior of the material for any accepted application. In this context, the setting of well-defined "end-of-waste" criteria, particularly in the Iberian Countries, is meaningful. 
Furthermore, the classification of "mirror entry", as set out in the LoW, itself results in major differences in IBA management among countries, as previously mentioned. The study carried out by Klymko et al. (2017) [105] for European IBA indicated that, from the 15 hazardous properties (HP) of waste that render it hazardous according to Commission Regulation 1357/2014, HP 10 (Toxic for reproduction) and HP 14 (Ecotoxic) are the ones possibly leading to the "hazardous waste" classification of IBA. Regarding HP 10, the study concluded that IBA is considered hazardous if the total content of $\mathrm{Pb}$ is above $3500 \mathrm{mg} / \mathrm{kg}$. In Portugal, the total content of $\mathrm{Pb}$ has been found to be below that limit both for mainland and island IBA (Table 3; Freire et al. [106]). Likewise, Spanish IBA has exhibited a total content of $\mathrm{Pb}$ below the threshold of $3500 \mathrm{mg} / \mathrm{kg}$ (Table 3). Regarding HP 14, related to potential environmental impacts, the classification is not that linear. By following the summation method (for total elemental concentrations) laid down in EU Council Regulation 2017/997 for HP 14 assessment, Klymko et al. (2017) found that IBA may be considered hazardous. However, considering total content and worst-case scenarios for elemental speciation likely leads to ecotoxicity overestimation and does not reflect the real hazard level of waste. HP 14 is responsible for most of the hazardous entries in the LoW [102,107]. Thus, the proper assessment of this hazardous property is of major importance to classify mirror entries. Moreover, "non-ecotoxic" classification through proper assessment should assist disqualification as waste, thus facilitating the valorization of the material. Currently, there is no consensus in the scientific community on the approach that should be followed to appropriately assess HP 14, and there are different proposals in the literature. Different authors have proposed methodologies involving leaching data and subsequent geochemical speciation modeling to find the relevant compounds for ecotoxicity prediction and the equilibrium concentrations on leachates $[105,108-110]$. On the other hand, different studies have focused on IBA ecotoxicity through biotests, covering both the aquatic and the terrestrial compartments [108,111-116]. Thus, the development and standardization of applicable methodologies for HP 14 assessment are needed for an accurate and informed evaluation of the environmental behavior of IBA.

In the EU Member States, including in Portugal and Spain, different approaches have been used for HP 14 assessment [73]. The Portuguese Environmental Agency has published a waste classification guide [117], recommending the assessment of HP 14 based on EU Regulation 2017/997. The guide states that there is no need to perform experimental assessment when that Regulation is followed. However, the EU Regulation 2017/997 indicates that it is possible to perform experimental tests following Regulation (EC) No. 440/2008 (for chemicals) or other internationally recognized methods. At the national level, there are no guidelines on biotests. In Spain, the assessment of HP 14 is performed based on biotests only, using the luminescence inhibition of the bacterium Vibrio fischeri (ISO 11348) or the lethality to Daphnia magna (ISO 6341). One of the two tests can be performed, and there is no need to perform both.

It should be noted that a potential classification as "hazardous waste" is not necessarily directly linked to the environmental risks associated with its use as a product and should not automatically lead to valorization barriers. Raw waste and products thereof may not have the same environmental impact. Thus, testing and requirements to prevent environmental impacts in this context should be considered despite this classification. Moreover, the consequences of this classification in other legislation pieces should be revised, possibly defending the circular economy if proper environmental protection measures can be adopted.

In fact, environmental contamination is one of the main concerns when using new materials. Despite the technical feasibility of using IBA in different applications, its environmental performance is still being discussed and is not broadly known. However, some studies in the literature have previously focused on the environmental impacts of some alternatives for IBA management. Using a life cycle assessment (LCA) methodology, Margallo et al. [118] evaluated the environmental impacts of different treatment alternatives targeting IBA, namely IBA solidification, IBA recycling in Portland cement 
production as a substitute for clinker, and for gypsum. A WtE plant from the north of Spain was the site of the case study. The results showed that ash solidification is the least favorable scenario due to the higher consumption of natural resources and emissions, leading to higher impacts on air and water. Among the recycling alternatives, a clinker substitution of $25 \%$ was indicated as the best scenario due to the lower consumption of natural resources and environmental burdens, regardless of the distance between the $\mathrm{WtE}$ plant and the cement facilities. Nonetheless, the distance had an important influence on the impact on water when decreasing the clinker substitution to $2.5 \%$ or substituting the ash for gypsum. Margallo et al. [119] also used an LCA to assess the environmental performance of the valorization of IBA to produce steel and aluminum from the recycling of metals and to produce cement. The study showed that the valorization of steel and aluminum recovered from IBA enables great energy savings in the steel and aluminum industries, which are energy-intensive sectors. Moreover, the utilization of IBA to produce cement reduced the consumption of natural resources $[90,119,120]$. Silva et al. [11] provided a literature review regarding the environmental performance of the utilization of IBA in construction-related products. The authors concluded that most of the revised studies favored the analysis of the leachability of the products containing IBA, focusing on the potential heavy metal contamination. Additionally, it was noticed that IBA utilization in the base and subbase layers for road pavement construction is the only IBA application in many countries and for that reason, it is most studied regarding its leaching behavior. It should be mentioned that IBA can be applied in granular form or hydraulically bound. Cement-bound IBA layers will probably have improved environmental behavior since heavy metal mobility during the road lifespan is likely to be limited considering their encapsulation inside the cementitious microstructure. The authors concluded that IBA utilization in road construction is more beneficial than landfilling, but the benefits may not be verified for high amounts of elements released if the leaching behavior of IBA is not properly controlled. With this in mind, the authors suggest that leaching trials must be required and drainage/rainwater collection systems should be considered to deviate water from the IBA-based layers. Moreover, natural weathering/aging prior to IBA utilization is referred to as a form of enhancing the environmental performance of those layers since that process creates a more stable material.

Finally, the significant differences in legal frameworks for IBA utilization within Europe contribute to the rather different management frameworks, since each country has its own criteria. A uniform regulatory framework at the EU level may enable IBA utilization as a secondary raw material in compliance with the same high standards of environmental protection in all EU member states.

Considering the high amounts of IBA produced and the growing concern for achieving a circular economy to reduce the amount of landfilled waste, it is foreseeable that more studies will be focused on this waste product, particularly regarding finding alternatives for its application while ensuring environmental protection. Despite the unwillingness to reuse waste (especially from MSW), provided the necessary and appropriate environmental studies confirming that this waste can be considered non-hazardous, it is expected that there will be a greater acceptance of its applications, which will necessarily boost the discussion regarding applicable legal frameworks. More confidence in IBA use, both in previously studied applications and in new fields still under development, should be obtained through changes in those frameworks and investment in IBA treatment.

\section{Concluding Remarks}

About $240 \mathrm{kt}$ /year and $474 \mathrm{kt} /$ year of IBA are produced in $4 \mathrm{WtE}$ plants in Portugal and 12 in Spain, respectively. IBA comprises a broad particle size distribution: finest particles include most soluble salts and potentially leachable heavy metal(loid)s, while the coarser parts mainly contain ceramics and glass. Nevertheless, natural weathering (2-3 months in the open) significantly reduces the leaching potential. IBA is considered nonhazardous in the Iberian countries. The utilization rate and criteria diverge in Portugal and 
Spain, as well as within these countries. Around $10 \%$ of Portuguese IBA and $41 \%$ in Spanish IBA are still landfilled. Around $15 \mathrm{kt}$ ( $6 \%$ of IBA) and $40 \mathrm{kt}$ (9\% of IBA) of metals have been recycled in Portugal and Spain, respectively. The remaining Portuguese IBA (84\%) is either temporarily stored $(11 \%)$, used in landfills for soil substitution in intermediate and final covers, construction of paths, accesses, and platforms (41\%), or in civil engineering work and road construction (48\%). The remaining Spanish IBA $(50 \%)$ is mainly used as secondary material in civil engineering or road construction $(77 \%)$, while only $4 \%$ is used in the conditioning of landfills and their surroundings and $19 \%$ is temporarily stored, awaiting future reuse. Both countries regulate the use of mineral IBA outside landfills, but differently. In Portugal, the National Civil Engineering Laboratory issues an individual permit to one processing plant (Valorsul). There is no specific legislation for IBA. The material (40\%) may be used in earthmoving works (landfills and pavement beds), layers/sub-base layers of roads, and landscape recovery of quarries or open-pit mines as filling material. In Spain, the use of IBA outside landfills (38\%) is only regulated in Catalonia and Cantabria, following different criteria but based on legislation specific to IBA. In Catalonia, IBA is permitted, e.g., in road subbase, leveling of terrain and embankments, filling, and restoration of degradable areas from extractive activities. In Cantabria, IBA can only be used as a secondary aggregate in road construction or concrete formulation.

Natural resources (e.g., aggregates) have been increasingly consumed, and the use of IBA can contribute to a real circular economy. The development of well-defined "endof-waste" criteria for IBA could be very relevant in EU countries, and Iberian countries in particular, favoring reuse while guaranteeing environmental protection. The "mirror entry" classification (LoW) of IBA also creates difficulties and divergences in reuse. The assessment of the HP 14 "ecotoxic" is the main challenge in the EU (including Iberia). A standard method for this assessment is essential, and according to the literature, after natural weathering of IBA, it is likely to be non-hazardous.

In the future, alternative applications will be increasingly studied, while ensuring environmental protection. Iberian countries would benefit if clear rules were proposed at the EU level.

Author Contributions: Data collection, B.S.B., M.J.Q., A.M.-A. and J.M.C.; supervision, J.L.P., R.C.M., M.J.Q. and J.M.C.; writing—original draft, B.S.B., A.M.-A. and J.M.C.; writing—review and editing, B.S.B., A.M.-A., J.L.P., R.C.M., M.J.Q. and J.M.C. All authors have read and agreed to the published version of the manuscript.

Funding: This research was funded by FCT/MCTES through UIDB/00102/2020, UIDP/50017/2020 + UIDB/50017/2020, and SFRH/BD/147920/2019.

Acknowledgments: Thanks are due to FCT/MCTES for their financial support to CIEPQPF (UIDB/ 00102/2020) and CESAM (UIDP/50017/2020 + UIDB/50017/2020) through national funds. B.S.B. is the recipient of an individual research grant by the FCT/MCTES with the reference SFRH/BD/ 147920/2019, through national funds and ESF (European Social Fund). J.M.C. and A.M.-A. are also grateful to the Catalan government for the DIOPMA (2017 SGR 118) quality accreditation awarded to their research group. The Portuguese WtE plants (Valorsul, LIPOR, ARM, and Teramb) are acknowledged for providing the data we requested. The authors also acknowledge AVALER and AEVERSU national associations for providing information.

Conflicts of Interest: The authors declare no conflict of interest.

\section{References}

1. Brunner, P.H. Cycles, spirals and linear flows. Waste Manag. Res. 2013, 31, 1-2. [CrossRef] [PubMed]

2. Quicker, P.; Consonni, S.; Grosso, M. The Zero Waste utopia and the role of waste-to-energy. Waste Manag. Res. 2020, 38, 481-484. [CrossRef]

3. Eurostat. Municipal Waste by Waste Management Operations. Available online: http://appsso.eurostat.ec.europa.eu/nui/ submitViewTableAction.do (accessed on 14 October 2020).

4. PERSU. Plano Estratégico Para os Resíduos Urbanos 2014-2020, Portaria n.o 187-A/2014, Publicada em DR (I Série) n.o 179. Available online: https:/ /dre.pt/pesquisa/- / search/56928479/details/maximized (accessed on 20 April 2021). 
5. APA. Relatório Anual Resíduos Urbanos 2019; Report by APA (Portuguese environmental agency); Agência Portuguesa do Ambiente-Departamento de Resíduos: Lisbon, Portugal, 2020.

6. Ministerio para la Transición Ecológica y el Reto Demográfico (MITECO). Memoria Anual de Generación y Gestión de Residuos Residuos de Competencia Municipal 2018; Secretaría de Estado de Medio Ambiente: Madrid, Spain, 2020. Available online: https://www. miteco.gob.es/es/calidad-y-evaluacion-ambiental/publicaciones/memoriaresiduosmunicipales2018_tcm30-521965.pdf (accessed on 10 February 2021).

7. PEMAR. Plan Estatal Marco de Gestión de Residuos (PEMAR) 2016-2022. Ministerio de Agricultura, Alimentación y Medio Ambiente. Available online: https:/ /www.miteco.gob.es/es/calidad-y-evaluacion-ambiental/planes-y-estrategias / ProgramadeprevencionaprobadoactualizadoANFABRA11022014_tcm30-192127.pdf (accessed on 10 February 2021).

8. Eurostat. Municipal Waste Statistics. Available online: https://ec.europa.eu/eurostat/statistics-explained/index.php/ Municipal_waste_statistics\#Municipal_waste_generation (accessed on 21 December 2020).

9. Eurostat. Municipal Waste Landfilled, Incinerated, Recycled and Composted, EU-28, 1995-2019. Available online: https:/ / ec.europa.eu/eurostat/statistics-explained/index.php?title=File:Municipal_waste_landfilled,_incinerated,_recycled_ and_composted,_EU-27,_1995-2019.png (accessed on 21 December 2020).

10. CEWEP-Confederation of European Waste-to-Energy Plants. What Is Waste-to-Energy-Incineration? Available online: https:/ / www.cewep.eu/what-is-waste-to-energy/ (accessed on 18 April 2020).

11. Silva, R.V.; de Brito, J.; Lynn, C.J.; Dhir, R.K. Environmental impacts of the use of bottom ashes from municipal solid waste incineration: A review. Resour. Conserv. Recycl. 2019, 140, 23-35. [CrossRef]

12. Chimenos, J.M.; Segarra, M.; Fernández, M.A.; Espiell, F. Characterization of the bottom ash in municipal solid waste incinerator. J. Hazard. Mater. 1999, 64, 211-222. [CrossRef]

13. Dou, X.; Ren, F.; Nguyen, M.Q.; Ahamed, A.; Yin, K.; Chan, W.P.; Chang, V.W.C. Review of MSWI bottom ash utilization from perspectives of collective characterization, treatment and existing application. Renew. Sustain. Energy Rev. 2017, 79, 24-38. [CrossRef]

14. CEWEP-Confederation of European Waste-to-Energy Plants. Bottom Ash Factsheet. Available online: http:/ / www.cewep.eu/ 2017/09/08/bottom-ash-factsheet/ (accessed on 11 March 2020).

15. Blasenbauer, D.; Huber, F.; Lederer, J.; Quina, M.J.; Blanc-Biscarat, D.; Bogush, A.; Bontempi, E.; Blondeau, J.; Chimenos, J.M.; Dahlbo, H.; et al. Legal situation and current practice of waste incineration bottom ash utilisation in Europe. Waste Manag. 2020, 102, 868-883. [CrossRef] [PubMed]

16. Pordata-Base de Dados Portugal Contemporâneo. Resíduos Urbanos: Total e por Tipo de Operação de Destino. Available online: https: / / www.pordata.pt/Portugal/Res $\{\{1\}\}$ duos+urbanos+total+e+por+tipo+de+operaç $\{\{\sim a\}\} 0+$ de+destino-1105 (accessed on 21 December 2020).

17. AVALER. Contributo da AVALER-Associação de Entidades de Valorização Energética de Resíduos para o Plano de Recuperação Económica de Portugal 2020-2030. Available online: http:/ / www.avaler.pt/media/12950/20200821_contributo-avaler-para-oplano-recupera\%C3\%A7\%C3\%A3o-econ\%C3\%B3mica-2030.pdf (accessed on 20 April 2021).

18. Park, Y.; Heo, J. Vitrification of fly ash from municipal solid waste incinerator. J. Hazard. Mater. 2002, 91, 83-93. [CrossRef]

19. APA—Agência Portuguesa de Ambiente. ERSAR—Entidade Reguladora dos Serviços de Águas e Resíduos. Orientações e Recomendações Para a Gestão de Resíduos em Situação de Pandemia por SARS-CoV-2 (COVID-19); APA: Lisbon, Portugal, 2020.

20. Margallo, M.; Aldaco, R.; Bala, A.; Fullana, P.; Irabien, Á. Best available techniques in municipal solid waste incineration: State of the art in Spain and Portugal. Chem. Eng. Trans. 2012, 29, 1345-1350. [CrossRef]

21. EEA-European Environment Agency. EMEP/EEA Air Pollutant Emission Inventory Guidebook 2019 Technical Guidance to Prepare National Emission Inventories; EEA Report No 13/2019; Publications Office of the European Union: Luxembourg, 2019.

22. BREF. Best Available Techniques (BAT) Reference Document for Waste Incineration-Industrial Emissions Directive 2010/75/EU (Integrated Pollution Prevention and Control); European Commission: Luxembourg, 2019.

23. Cheremisinoff, N.P. Handbook of Solid Waste Management and Waste Minimization Technologies; Butterworth-Heinemann: Burlington, MA, USA, 2003.

24. Quina, M.J.; Bordado, J.C.M.; Quinta-Ferreira, R.M. Air Pollution Control of Municipal Solid Waste Incinerators. In The Impact of Air Pollution on Health, Economy, Environment and Agricultural Sources; Khallaf, M.K., Ed.; InTech.: Rijeka, Croatia, 2011; pp. 331-358.

25. The International Bank for Reconstruction and Development/The World Bank. World Bank Technical Guidance Report-Municipal Solid Waste Incineration; The World Bank: Washington, DC, USA, 1999.

26. AVALER-Associação de Entidades de Valorização Energética de Resíduos. Indicadores AVALER, Valorização Energética de Resíduos em Portugal. Available online: http://www.avaler.pt/informacao-tecnica/indicadores-avaler/ (accessed on 10 January 2021).

27. ARM—Águas e Resíduos da Madeira. A IIRSU—Instalação de Incineração de Resíduos Sólidos Urbanos. Available online: http:/ / www.aguasdamadeira.pt/Portals/0/Documentos/Instalaç\{\{ o\}\}es/ETRS-IIRSU.pdf (accessed on 22 December 2020).

28. DRA—Direção Regional do Ambiente da Região Autónoma dos Açores. Licença Ambiental LA n.o 3/2014/DRA, TERAMB—Empresa Municipal de Gestão e Valorização Ambiental da Ilha Terceira, EEM; Environmental License; DRA: Horta, Portugal, 2014.

29. LIPOR. Valorização Energética. Available online: https://www.lipor.pt/pt/valorizar/valorizacao-energetica/ (accessed on 22 December 2020). 
30. Valorsul. Valorização Energética. Available online: http://www.valorsul.pt/pt/seccao/areas-de-negocio/valorizacaoenergetica/ (accessed on 22 December 2020).

31. AEVERSU. Estudio Sobre los Impactos Socio-Económicos y Ambientales de la Valorización Energética de los Residuos Urbanos en España y Andorra. 2015. Available online: http://www.sogama.gal/sites/default/files/users/1/AEVERSU_informefinal_30 72015.pdf (accessed on 10 February 2021).

32. GHK. Gipuzkoako Hondakinen Kudeaketa S.A.U. Available online: https://www.ghk.eus/inicio.htm (accessed on 10 February 2021).

33. TERSA. Tractament i Selecció de Residus, S.A. Available online: https://www.tersa.cat/en (accessed on 10 February 2021).

34. URBASER. Tratamiento de Residuos Municipales. Available online: https://www.urbaser.com/areas-de-actividad/tratamientode-residuos / tratamiento-de-residuos-municipales / (accessed on 10 February 2021).

35. Zabalgarbi, S.A. Available online: http://www.zabalgarbi.com/en/ (accessed on 10 February 2021).

36. Siddiqi, M.M.; Naseer, M.N.; Wahab, Y.A.; Hamizi, N.A.; Badruddin, I.A.; Chowdhury, Z.Z.; Akbarzadeh, O.; Johan, M.R.; Khan, T.M.Y.; Kamangar, S. Evaluation of Municipal Solid Wastes Based Energy Potential in Urban Pakistan. Processes 2019, 7, 848. [CrossRef]

37. Rendek, E.; Ducom, G.; Germain, P. Influence of waste input and combustion technology on MSWI bottom ash quality. Waste Manag. 2007, 27, 1403-1407. [CrossRef]

38. Alhassan, H.M.; Tanko, A.M. Characterization of solid waste incinerator bottom ash and the potential for its use Characterization of Solid Waste Incinerator Bottom Ash and the Potential for its Use. Int. J. Eng. Res. Appl. 2012, 2, 516-522.

39. Yin, K.; Chan, W.P.; Dou, X.; Ren, F.; Wei-Chung, C.V. Cr, Cu, Hg and Ni release from incineration bottom ash during utilization in land reclamation-based on lab-scale batch and column leaching experiments and a modeling study. Chemosphere 2018, 197, 741-748. [CrossRef]

40. Joseph, A.M.; Snellings, R.; Van den Heede, P.; Matthys, S.; De Belie, N. The use of municipal solidwaste incineration ash in various building materials: A Belgian point of view. Materials 2018, 11, 141. [CrossRef]

41. Seniunaite, J.; Vasarevicius, S. Leaching of copper, lead and zinc from municipal solid waste incineration bottom ash. Energy Procedia 2017, 113, 442-449. [CrossRef]

42. Wiles, C.C. Municipal solid waste combustion ash: State-of-the-knowledge. J. Hazard. Mater. 1996, 47, 325-344. [CrossRef]

43. AVALER. Indicadores AVALER-Valorização Energética de Resíduos em Portugal. Available online: http:/ /www.avaler.pt/ informacao-tecnica/indicadores-avaler/ (accessed on 27 April 2021).

44. LIPOR. Relatório Integrado 2019; LIPOR: Porto, Portugal, 2019.

45. Siaram. Direção Regional do Ambiente do Governo dos Açores. Valorização Energética dos Resíduos-Ilha Terceira. Available online: http:/ / siaram.azores.gov.pt/residuos/Central-de-Valorizacao-Energetica/Valorizacao-Energetica-Residuos.pdf (accessed on 5 January 2021).

46. Valorsul. Relatório e Contas 2019; ValorsuL: Lisbon, Portugal, 2019.

47. AEVERSU. Asociación de Empresas de Valorización Energética de Residuos Urbanos. Available online: https: / /aeversu.org/ (accessed on 10 February 2021).

48. TIRME. Parque de Tecnología Ambientales de Mallorca. Available online: https://www.tirme.com/es/index.html (accessed on 19 April 2021).

49. Huber, F.; Blasenbauer, D.; Aschenbrenner, P.; Fellner, J. Complete determination of the material composition of municipal solid waste incineration bottom ash. Waste Manag. 2020, 102, 677-685. [CrossRef] [PubMed]

50. Almeida, F.; Carneiro, J.R.; Lopes, M.D.L. Use of incinerator bottom ash as a recycled aggregate in contact with nonwoven geotextiles: Evaluation of mechanical damage upon installation. Sustainability 2020, 12, 9156. [CrossRef]

51. Lopes, M.G. Reciclagem de Escórias de Incineração de RSU como Agregados para a Construção. Master's Internship Report in Materials Engineering, University of Aveiro, Aveiro, Portugal, 2010.

52. Reis-Barros, J.; Lopes, M.G.; Correia, A.G. Escórias de R.S.U.: Caracterização mecânica para fins rodoviários. In CONGRESSO NACIONAL DE GEOTECNIA, 10, Lisboa, Portugal, 2006- “Geotecnica multidisciplinar: Ambiente/sísmica". [S.l.]; Sociedade Portuguesa de Geotecnia: Lisboa, Portugal, 2006; Volume 3, pp. 753-763.

53. Izquierdo, M.; López-Soler, Á.; Vazquez, E.; Barra, M.; Querol, X. Characterisation of bottom ash from municipal solid waste incineration in Catalonia. J. Chem. Technol. Biotechnol. 2002, 77, 576-583. [CrossRef]

54. del Valle-Zermeño, R.; Gómez-Manrique, J.; Giro-Paloma, J.; Formosa, J.; Chimenos, J.M. Material characterization of the MSWI bottom ash as a function of particle size. Effects of glass recycling over time. Sci. Total Environ. 2017, 581-582, 897-905. [CrossRef]

55. Maldonado-Alameda, A.; Giro-Paloma, J.; Svobodova-Sedlackova, A.; Formosa, J.; Chimenos, J.M. Municipal solid waste incineration bottom ash as alkali-activated cement precursor depending on particle size. J. Clean. Prod. 2020, 242, 118443. [CrossRef]

56. Luo, H.; Cheng, Y.; He, D.; Yang, E.H. Review of leaching behavior of municipal solid waste incineration (MSWI) ash. Sci. Total Environ. 2019, 668, 90-103. [CrossRef]

57. Chimenos, J.M.; Fernández, A.I.; Nadal, R.; Espiell, F. Short-term natural weathering of MSWI bottom ash. J. Hazard. Mater. 2000, 79, 287-299. [CrossRef]

58. Chimenos, J.M.; Fernández, A.I.; Miralles, L.; Segarra, M.; Espiell, F. Short-term natural weathering of MSWI bottom ash as a function of particle size. Waste Manag. 2003, 23, 887-895. [CrossRef] 
59. Monteiro, R.C.C.; Figueiredo, C.F.; Alendouro, M.S.; Ferro, M.C.; Davim, E.J.R.; Fernandes, M.H.V. Characterization of MSWI bottom ashes towards utilization as glass raw material. Waste Manag. 2008, 28, 1119-1125. [CrossRef] [PubMed]

60. Cristelo, N.; Segadães, L.; Coelho, J.; Chaves, B.; Sousa, N.R.; Lopes, M.D.L. Recycling municipal solid waste incineration slag and fly ash as precursors in low-range alkaline cements. Waste Manag. 2020, 104, 60-73. [CrossRef] [PubMed]

61. SOGAMA. Sociedade Galega do Medio Ambiente. Available online: http:/ / www.sogama.gal/es (accessed on 10 February 2021).

62. Van Der Sloot, H.A.; Kosson, D.S.; Hjelmar, O. Characteristics, treatment and utilization of residues from municipal waste incineration. Waste Manag. 2001, 21, 753-765. [CrossRef]

63. Weibel, G.; Eggenberger, U.; Kulik, D.A.; Hummel, W.; Schlumberger, S.; Klink, W.; Fisch, M.; Mäder, U.K. Extraction of heavy metals from MSWI fly ash using hydrochloric acid and sodium chloride solution. Waste Manag. 2018, 76, $457-471$. [CrossRef] [PubMed]

64. Crillesen, K.; Skaarup, J.; Bojsen, K. Management of Bottom Ash from WTE Plants-An Overview of Management Options and Treatment Methods; ISWA Working Group Thermal Treatment: Copenhagen, Denmark, 2006.

65. del Valle-zermeño, R.; Chimenos, J.M.; Giró-paloma, J.; Formosa, J. Use of weathered and fresh bottom ash mix layers as a subbase in road constructions: Environmental behavior enhancement by means of a retaining barrier. Chemosphere 2014, 117, 402-409. [CrossRef]

66. Fuchs, B.; Track, C.; Lang, S.; Gimmler, H. Salt effects of processed municipal solid waste incinerator bottom ash on vegetation and underground water. J. Appl. Bot. Food Qual. 1997, 71, 154-163.

67. Shih, H.C.; Ma, H.W. Life cycle risk assessment of bottom ash reuse. J. Hazard. Mater. 2011, 190, 308-316. [CrossRef] [PubMed]

68. Shih, H.C.; Ma, H.W. Assessing the health risk of reuse of bottom ash in road paving. Chemosphere 2011, 82, 1556-1562. [CrossRef] [PubMed]

69. Alam, Q.; Schollbach, K.; Hoek, C.V.; Laan, S.V.D.; Wolf, T.D.; Brouwers, H.J.H. In-depth mineralogical quantification of MSWI bottom ash phases and their association with potentially toxic elements. Waste Manag. 2019, 87, 1-12. [CrossRef] [PubMed]

70. Chen, C.H.; Chiou, I.J. Distribution of chloride ion in MSWI bottom ash and de-chlorination performance. J. Hazard. Mater. 2007, 148, 346-352. [CrossRef]

71. Tang, J.; Steenari, B.M. Leaching optimization of municipal solid waste incineration ash for resource recovery: A case study of Cu, $\mathrm{Zn}, \mathrm{Pb}$ and $\mathrm{Cd}$. Waste Manag. 2016, 48, 315-322. [CrossRef]

72. Xia, Y.; He, P.; Shao, L.; Zhang, H. Metal distribution characteristic of MSWI bottom ash in view of metal recovery. J. Environ. Sci. 2017, 52, 178-189. [CrossRef]

73. BIO by Deloitte. Study to Assess the Impacts of Different Classification Approaches for Hazard Property "HP 14" on Selected Waste Streams-Final Report; Prepared for the European Commission (DG ENV), in collaboration with INERIS; BIO by Deloitte: London, UK, 2015.

74. Stiernström, S.; Wik, O.; Bendz, D. Evaluation of frameworks for ecotoxicological hazard classification of waste. Waste Manag. 2016, 58, 14-24. [CrossRef]

75. Oehmig, W.N.; Roessler, J.G.; Zhang, J.; Townsend, T.G. Effect of ferrous metal presence on lead leaching in municipal waste incineration bottom ashes. J. Hazard. Mater. 2015, 283, 500-506. [CrossRef]

76. Neuwahl, F.; Cusano, G.; Benavides, J.G.; Holbrook, S.; Serge, R. Best Available Techniques (BAT) Reference Document for Waste Incineration. Industrial Emissions Directive 2010/75/EU (Integrated Pollution Prevention); Science for Policy report by the Joint Research Centre, European Commission: Luxembourg, 2019.

77. Dhir, R.K.; De Brito, J.; Lynn, C.J.; Silva, R.V. Sustainable Construction Materials: Municipal Incinerator Bottom Ashes; Woodhead Publishing: Duxford, UK, 2018.

78. Baciocchi, R.; Costa, G.; Lategano, E.; Marini, C.; Polettini, A.; Pomi, R.; Postorino, P.; Rocca, S. Accelerated carbonation of different size fractions of bottom ash from RDF incineration. Waste Manag. 2010, 30, 1310-1317. [CrossRef] [PubMed]

79. Cornelis, G.; Gerven, T.V.; Vandecasteele, C. Antimony leaching from uncarbonated and carbonated MSWI bottom ash. J. Hazard. Mater. 2006, 137, 1284-1292. [CrossRef]

80. Cornelis, G.; Gerven, T.V.; Vandecasteele, C. Antimony leaching from MSWI bottom ash: Modelling of the effect of pH and carbonation. Waste Manag. 2012, 32, 278-286. [CrossRef]

81. Shimaoka, T.; Zhang, R.; Watanabe, K. Alterations of municipal solid waste incineration residues in a landfill. Waste Manag. 2007, 27, 1444-1451. [CrossRef] [PubMed]

82. Wei, Y.; Saffarzadeh, A.; Shimaoka, T.; Zhao, C.; Peng, C.; Gao, J. Geoenvironmental weathering/deterioration of landfilled MSWI-BA glass. J. Hazard. Mater. 2014, 278, 610-619. [CrossRef] [PubMed]

83. Wei, Y.; Shimaoka, T.; Saffarzadeh, A.; Takahashi, F. Alteration of municipal solid waste incineration bottom ash focusing on the evolution of iron-rich constituents. Waste Manag. 2011, 31, 1992-2000. [CrossRef] [PubMed]

84. Wei, Y.; Shimaoka, T.; Saffarzadeh, A.; Takahashi, F. Mineralogical characterization of municipal solid waste incineration bottom ash with an emphasis on heavy metal-bearing phases. J. Hazard. Mater. 2011, 187, 534-543. [CrossRef]

85. Siddique, R. Utilization of municipal solid waste (MSW) ash in cement and mortar. Resour. Conserv. Recycl. 2010, 54, 1037-1047. [CrossRef]

86. Jurič, B.; Hanžicč, L.; Ilić, R.; Samec, N. Utilization of municipal solid waste bottom ash and recycled aggregate in concrete. Waste Manag. 2006, 26, 1436-1442. [CrossRef] 
87. Ginés, O.; Chimenos, J.M.; Vizcarro, A.; Formosa, J.; Rosell, J.R. Combined use of MSWI bottom ash and fly ash as aggregate in concrete formulation: Environmental and mechanical considerations. J. Hazard. Mater. 2009, 169, 643-650. [CrossRef] [PubMed]

88. Pecqueur, G.; Crignon, C.; Quénée, B. Behaviour of cement-treated MSWI bottom ash. Waste Manag. 2001, 229-233. [CrossRef]

89. Silva, R.V.; de Brito, J.; Lynn, C.J.; Dhir, R.K. Use of municipal solid waste incineration bottom ashes in alkali-activated materials, ceramics and granular applications: A review. Waste Manag. 2017, 68, 207-220. [CrossRef]

90. Maldonado-Alameda, Â.; Giro-Paloma, J.; Alfocea-Roig, A.; Formosa, J.; Chimenos, J.M. Municipal solid waste incineration bottom ash as sole precursor in the alkali-activated binder formulation. Appl. Sci. 2020, 10, 4129. [CrossRef]

91. ARM. Águas e Resíduos da Madeira. Relatorio e Contas 2019; Funchal: Madeira Island, Portugal, 2019.

92. Teramb. Relatório de Gestão e Contas 2019; Teramb: Terceira Island, Portugal, 2019.

93. Valorsul. Instalação de Tratamento e Valorização de Escórias. Available online: http://www.valorsul.pt/pt/seccao/areas-denegocio/valorizacao-de-escorias/instalacao-de-tratamento-e-valorizacao-de-escorias. (accessed on 22 January 2021).

94. LNEC—Laboratório Nacional de Engenharia Civil. Documento de Aplicação. AEIRU—Agregados Artificiais de Escórias de Incineração de Resíduos Urbanos para Pavimentos Rodoviários; Individual permit issued by LNEC (Portuguese National Civil Engineering Laboratory); LNEC: Lisboa, Portugal, 2015.

95. Leder, J.; Syc, M.; Biganzoli, L.; Bogush, A.; Bontempi, E.; Braga, R.; Costa, G.; Funari, V.; Grosso, M.; Hyks, J.; et al. Recovery technologies for waste incineration residues (MINEA Deliverable). Mining the European Antroposphere (MINEA). 2018. Available online: http:/ / www.minea-network.eu/upload/D31Report.pdf. (accessed on 24 May 2020).

96. DOGC. Ordre de 15 de Febrer de 1996, Sobre Valorització D'escòries. Available online: http://residus.gencat.cat/web/.content/ home/consultes_i_tramits/normativa/normativa_catalana_en_materia_de_residus/ordrePlease_15021996.pdf (accessed on 27 April 2021).

97. BOC. Decreto 100/2018, de 20 de Diciembre, de Valorización de Escorias en la Comunidad Autónoma de Cantabria. Available online: https:/ / boc.cantabria.es/boces/verAnuncioAction.do?idAnuBlob=333876 (accessed on 27 April 2021).

98. OECD. Global Material Resources Outlook to 2060: Economic Drivers and Environmental Consequences; OECD Publishing: Paris, France, 2019; ISBN 9789264307452.

99. Valorsul. Agregado para Construção Rodoviária. Available online: http://www.valorsul.pt/pt/seccao/areas-de-negocio/ produtos/agregado-para-construcao-rodoviaria (accessed on 22 January 2021).

100. European Commission. Environment Action Programme to 2020. Available online: https:/ / ec.europa.eu/environment/actionprogramme/ (accessed on 24 May 2020).

101. European Commission. A European Green Deal. Available online: https://ec.europa.eu/info/strategy/priorities-2019-2024/ european-green-deal_en\#latest (accessed on 24 May 2020).

102. Pandard, P.; Devillers, J.; Charissou, A.M.; Poulsen, V.; Jourdain, M.J.; Férard, J.F.; Grand, C.; Bispo, A. Selecting a battery of bioassays for ecotoxicological characterization of wastes. Sci. Total Environ. 2006, 363, 114-125. [CrossRef]

103. Verbinnen, B.; Billen, P.; Van Caneghem, J.; Vandecasteele, C. Recycling of MSWI Bottom Ash: A Review of Chemical Barriers, Engineering Applications and Treatment Technologies. Waste Biomass Valorization 2017, 8, 1453-1466. [CrossRef]

104. Velzeboer, I.; Van Zomeren, A. End of Waste Criteria for Inert Aggregates in Member States; ECN (Energy Research Centre of The Netherlands): Petten, The Netherlands, 2017. Available online: https:/ / publicaties.ecn.nl/PdfFetch.aspx?nr=ECN-E--17-010 (accessed on 20 May 2021).

105. Klymko, T.; Dijkstra, J.J.; van Zomeren, A. Guidance Document on Hazard Classification of MSWI Bottom Ash; ECN (Energy Research Centre of The Netherlands): Petten, The Netherlands, 2017. Available online: https:/ / publicaties.ecn.nl/PdfFetch.aspx?nr=ECNE--17-024 (accessed on 20 May 2021).

106. Freire, A.C.; Antunes, M.L.; Dinis de Sousa, C. Application of Municipal Solid Waste Incineration Bottom Ash in Road Construction. A Case Study. In Proceedings of the 4th International SIIV Congress Advances in Transport Infrastructures and Stakeholders Expectations, Palermo, Italy, 12-14 September 2007.

107. Hennebert, P. Proposal of concentration limits for determining the hazard property HP 14 for waste using ecotoxicological tests. Waste Manag. 2018, 74, 74-85. [CrossRef]

108. Wahlström, M.; Laine-Ylijok, J.; Wik, O.; Oberender, A.; Hjelmar, O. Hazardous Waste Classification: Amendments to the European Waste Classification Regulation-What do They Mean and What Are the Consequences? Report for the Nordic Council of Ministers; TemaNord: Copenhagen, Denmark, 2016.

109. WRc. Assessment of Hazard Classification of UK IBA; Report for the January-June 2011 IBA Dataset, Report for Environmental Services Association, WRc Reference: UC8540.06; WRc: Wiltshire, UK, 2012.

110. Hjelmar, O.; Van Der Sloot, H.A.; Van Zomeren, A. Hazard Property Classification of High Temperature Waste Materials. In Proceedings Sardinia 2013, Fourteenth International Waste Management and Landfill Symposium, S. Margherita di Pula, Cagliari, Italy, 30 September-4 October 2013; CISA Publisher: Cagliari, Italy, 2013.

111. Ferrari, B.; Radetski, C.M.; Veber, A.M.; Ferard, J.F. Ecotoxicological assessment of solid wastes: A combined liquid- and solid-phase testing approach using a battery of bioassays and biomarkers. Environ. Toxicol. Chem. 1999, 18, 1195-1202. [CrossRef]

112. Lapa, N.; Barbosa, R.; Morais, J.; Mendes, B.; Méhu, J.; Santos Oliveira, J.F. Ecotoxicological assessment of leachates from MSWI bottom ashes. Waste Manag. 2002, 22, 583-593. [CrossRef]

113. Moser, H.; Römbke, J. Ecotoxicological Characterization of Waste-Results and Experiences of a European Ring Test; Springer Ltd.: New York, NY, USA, 2009; ISBN 9780387889580. 
114. Römbke, J.; Moser, T.; Moser, H. Ecotoxicological characterisation of 12 incineration ashes using 6 laboratory tests. Waste Manag. 2009, 29, 2475-2482. [CrossRef]

115. Pandard, P.; Römbke, J. Proposal for a "Harmonized" strategy for the assessment of the HP 14 property. Integr. Environ. Assess. Manag. 2013, 9, 665-672. [CrossRef] [PubMed]

116. Ribé, V.; Nehrenheim, E.; Odlare, M. Assessment of mobility and bioavailability of contaminants in MSW incineration ash with aquatic and terrestrial bioassays. Waste Manag. 2014, 34, 1871-1876. [CrossRef]

117. APA-Agência Portuguesa de Ambiente. Guia de Classificação de Resíduos; APA: Lisbon, Portugal, 2020.

118. Margallo, M.; Aldaco, R.; Irabien, Á. Environmental management of bottom ash from municipal solid waste incineration based on a life cycle assessment approach. Clean Technol. Environ. Policy 2014, 16, 1319-1328. [CrossRef]

119. Margallo, M.; Aldaco, R.; Bala, A.; Fullana, P.; Irabien, A. Contribution to closing the loop on waste materials: Valorization of bottom ash from waste-to-energy plants under a life cycle approach. J. Mater. Cycles Waste Manag. 2018, 20, 1507-1515. [CrossRef]

120. Maldonado-Alameda, A.; Mañosa, J.; Giro-Paloma, J.; Formosa, J.; Chimenos, J.M. Alkali-Activated Binders Using Bottom Ash from Waste-to-Energy Plants and Aluminium Recycling Waste. Appl. Sci. 2021, 11, 3840. [CrossRef] 